\title{
Construction of a large-scale semi-field facility to study genotypic differences in deep root growth and resources acquisition
}

\author{
Simon Fiil Svane ${ }^{1^{*}} \mathbb{D}$, Christian Sig Jensen ${ }^{2}$ and Kristian Thorup-Kristensen ${ }^{1}$
}

\begin{abstract}
Background: Roots are vital organs for plants, and the effective use of resources from the soil is important for yield stability. However, phenotypic variation in root traits among crop genotypes is mostly unknown and field screening of root development is costly and labour demanding. As a consequence, new methods are needed to investigate root traits of fully grown crops under field conditions, particularly roots in the deeper soil horizons.

Results: We developed a new phenotyping facility (RadiMax) for the study of root growth and soil resource acquisition under semi-field conditions. The facility consists of 4 units each covering $400 \mathrm{~m}^{2}$ and containing 150 minirhizotrons, allowing root observation in the $0.4 \mathrm{~m}-1.8 \mathrm{~m}$ or $0.7 \mathrm{~m}-2.8 \mathrm{~m}$ soil depth interval. Roots are observed through minirhizotrons using a multispectral imaging system. Plants are grown in rows perpendicular to a water stress gradient created by a multi-depth sub-irrigation system and movable rainout shelters. The water stress gradient allows for a direct link between root observations and the development of stress response in the canopy.

Conclusion: To test the concept and technical features, selected spring barley (Hordeum vulgare L.) cultivars were grown in the system for two seasons. The system enabled genotypic differences for deep root growth to be observed, and clear aboveground physiological response was also visible along the water stress gradient. Although further technical development and field validation are ongoing, the semi-field facility concept offers novel possibilities for characterising genotypic differences in the effective use of soil resources in deeper soil layers.
\end{abstract}

Keywords: Drought, Minirhizotron, Nitrogen, Phenotyping, Root, Semi-field, Soil, Water

\section{Background}

Effective use of water and nutrients is important to ensure a sustainable crop production. In Europe future droughts are expected to set in more quickly and be more intense [1,2]. At the same time, new measures are needed to reduce the nitrogen $(\mathrm{N})$ pollution of the environment [3]. During dry conditions, the ability of deep and vigorous root growth to utilize deep subsoil water is important [4-6]. Furthermore, acquisition of leached $\mathrm{N}$ in deeper soil layers could improve nitrogen use efficiency (NUE) and reduce $\mathrm{N}$ losses to the environment [7-9].

\footnotetext{
*Correspondence: sfs@plen.ku.dk

${ }^{1}$ Department of Plant and Environmental Science, University

of Copenhagen, 1871 Frederiksberg, Denmark

Full list of author information is available at the end of the article
}

Plant breeders have largely focused on shoot parameters as they seek new plant varieties that have better yield potential and other desirable qualities. Considerable effort is needed to obtain information about the entire root system, since most crop species extend their roots to soil layers deeper than $1 \mathrm{~m}$ [10]. Excavations of complete root system have been attempted [11, 12] and has provided data regarding overall root system architecture. Auger sampling followed by root washing and trench wall methods has provided some relief [13]. Over time, further attempts to reduce workload range from field-based methods on mature root systems to more indirect methods of early root growth in greenhouse systems (controlled environment).

For field phenotyping, the core break method [14, 15] and minirhizotron (MR) method $[7,16,17]$ have become

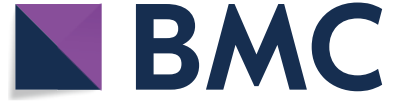

(c) The Author(s) 2019. This article is distributed under the terms of the Creative Commons Attribution 4.0 International License (http://creativecommons.org/licenses/by/4.0/), which permits unrestricted use, distribution, and reproduction in any medium, provided you give appropriate credit to the original author(s) and the source, provide a link to the Creative Commons license, and indicate if changes were made. The Creative Commons Public Domain Dedication waiver (http://creativecommons.org/ publicdomain/zero/1.0/) applies to the data made available in this article, unless otherwise stated. 
widely used alternatives to root studies made by complete excavations. Neither methods require time-consuming procedures for washing roots that have been extracted from soil samples. MR studies offer the further advantage of repeated measurements over time. On the other hand, MR studies are often hampered by soil smearing during tube installation, poor tube-to-soil contact and overestimation of deep root intensities if roots grow preferentially along the tube surface [18-21]. However, by careful horizontal insertion techniques, such artifacts can be reduced [19]. However, both core break and MR techniques suffer from a time-consuming bottleneck: the subsequent manual quantification of root structures.

Other methods in use focus on indirect but easily quantifiable "proxy traits". Methods such as the "Shovelomics" approach, have been used to identify genetic differences in larger populations of maize [22]. Some methods combine newly developed and low-cost Unmanned Aerial Systems (UAS-imaging) to identify drought-related stress symptoms [23]. Finally, multiple proxy-trait screening systems offer rapid detection under controlled greenhouse conditions e.g. [24-28]. Field tests have shown a good correlation between proxy traits such as seminal root angle and performance in the field, but the direction and magnitude of correlations varied across environments $[29,30]$. To improve detection and validation of desirable proxy traits, a screening system can be run in parallel to field validation in different target environments as suggested by [5]. Thus, new methods to study the actual deep root development of crops grown to their full development in field conditions, will be beneficial both for validation of existing methods and improve the understanding of the relationships between proxy traits and actual root development in deeper soil horizons.

Here we describe a new phenotyping infrastructure for the identification of plant material capable of utilizing water and nutrients in deeper soil layers. The semi-field approach allows for a high degree of control of soil and climatic factors between seasons, but in an environment that closely resembles field conditions. Furthermore the facility is large enough to include many genotypes having 300 rows available for each experiment. Our facility enables root measurements to be coupled directly with observations of canopy drought stress symptoms induced by controlled water stress. This paper includes results from a 2-year replicated spring barley experiment to illustrate the design and function.

\section{Materials and methods Outline of the facility}

The RadiMax facility is located at Copenhagen University's experimental farm (Latitude $55.66815^{\circ} \mathrm{N}$, Longitude

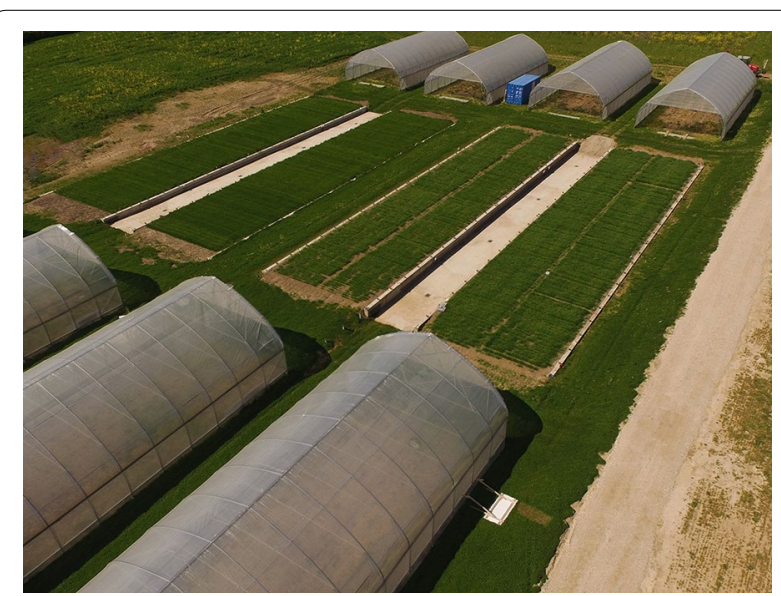

Fig. 1 Overview of the phenotyping facility in May 2017. Spring barley was established in units 1 and 2 (front). Perennial ryegrass was grown in units 3 and 4 (photo by Jesper Svensgaard, 2017)

$\left.12.30848^{\circ} \mathrm{E}\right)$, west of Copenhagen, Denmark and at an elevation of $26 \mathrm{~m}$ above sea level (Fig. 1). The experimental space includes four units each with a net area of $9.7 \times 40 \mathrm{~m}$. The units comprise two pairs consisting of two units each connected by a 4-m center aisle (Fig. 2). Each unit has concrete walls and a V-shaped bottom lined with an impermeable plastic membrane. The soil profile consists of repacked soil with two distinct soil layers, topsoil 0-0.4 $\mathrm{m}$ with subsoil below. One pair of units (1 and 2), designed for deep-rooted crops, has a soil depth that increases from $1.1 \mathrm{~m}$ at the sides to $3.0 \mathrm{~m}$ in the middle (Fig. 2), while soil depth in the other pair ranges $0.8 \mathrm{~m}$ to $2.1 \mathrm{~m}$.

Transparent tubes for root observations (minirhizotrons, MR) were installed $40 \mathrm{~cm}$ above the sloping bottom. At one end, the tubes were led through holes in the concrete wall that faces the central aisle; at the other end, the tubes were led towards a central connection tube above a central drain (Figs. 2, 3d). The MR tubes thus enable photography of roots ranging from a soil depth of $0.70 \mathrm{~m}$ to $2.70 \mathrm{~m}$ for units 1 and 2 , and from $0.40 \mathrm{~m}$ to $1.80 \mathrm{~m}$ for units 3 and 4 . A total of $600 \mathrm{MR}$ tubes (PMMA-Plastic) with a $70 \mathrm{~mm}$ outer diameter, $60 \mathrm{~mm}$ inner diameter and a total length of $5.5 \mathrm{~m}$ were placed, $25 \mathrm{~cm}$ apart, in the four units (150 in each).

Two moveable rainout shelters were constructed for each unit, making it possible to cover the units in rainy periods (see Fig. 1). A steel frame of $22 \mathrm{~m} \times 10 \mathrm{~m} \times 4.9 \mathrm{~m}$ $(\mathrm{L} \times \mathrm{W} \times \mathrm{H})$ forms a tunnel greenhouse with straight sides $(1.75 \mathrm{~m}$ ), type RS 99300 (Rovero, Ramsdonksveer, $\mathrm{NL}$ ). The roof of the shelters is constructed with three layers of plastic film (TPT, Solar Eva 5) with a light transmission of $91 \%$. The open ends provide ventilation and a transparent insect net (Mesh size $0.39 \mathrm{~mm} \times 0.88 \mathrm{~mm}$ ) was used as wall cladding to allow airflow and reduce 

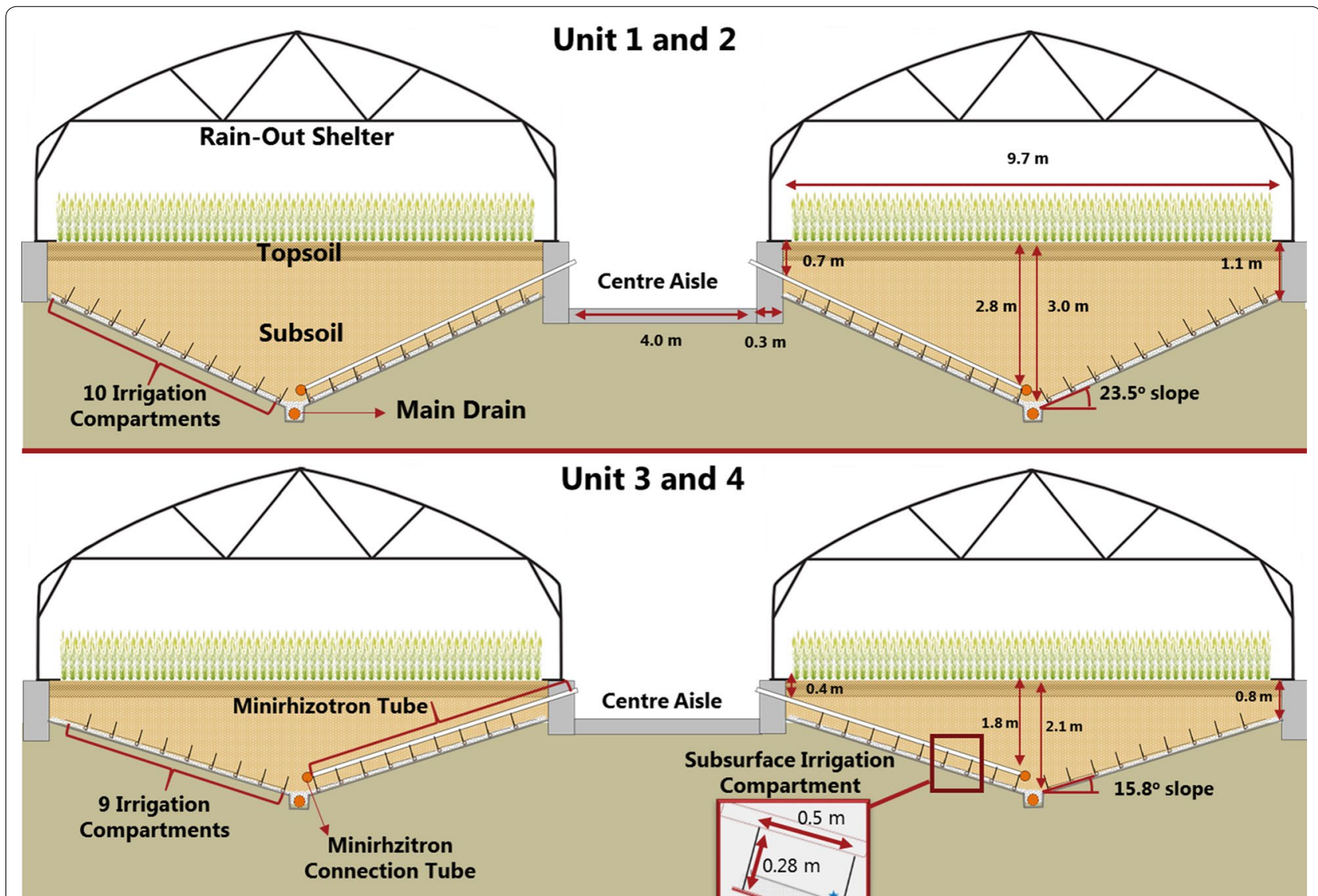

Unit 3 and 4

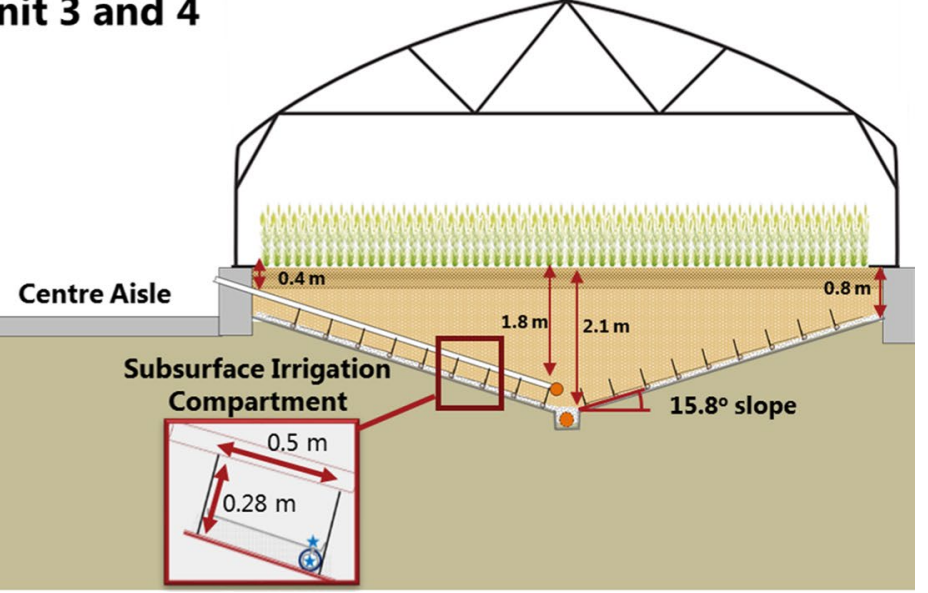

Fig. 2 Cross-section of the four units in the RadiMax facility

warming effects, but still prevent rain from entering from the side. When not in use, the shelters are parked $10 \mathrm{~m}$ to the east and west of the units (Fig. 2).

\section{Subsurface irrigation system}

A water supply gradient was created by a subsurface irrigation system placed at the bottom of each unit. After water has been emitted from driplines placed at the bottom, the system uses the principle of capillary movement to distribute water without the assistance of external forces (Fig. 3e). Premade irrigation tubes $(\varnothing 70 \mathrm{~mm})$ were installed in the bottom of each compartment. Each tube is open along its upper side having a coating of polyester textile (Breatex450, Fibertex, Aalborg, Denmark) providing direct capillary contact with the soil above. By placing the polyester textile above a $10 \mathrm{~cm}$ layer of prewashed stones $(16-32 \mathrm{~mm})$ a capillary barrier is formed between the soil and the bottom (Fig. 3). The compartments are separated by $0.28 \mathrm{~m}$ tall bulkheads of steel-supported PVC plates, installed at a $90^{\circ}$ angle to the bottom and at a distance of $50 \mathrm{~cm}$ (Fig. 3c). Bulkheads reduce horizontal flow and function as support for the MR tubes. To allow for release of water over the entire length of the facility, a pressure-compensated dripline system was used (UniRam ${ }^{\mathrm{TM}}$ HNCL (Netafim, Tel Aviv, Israel). Each compartment contains two driplines. One dripline was placed within the irrigation tube and the other directly above the tube in the interlayer between the soil and the wick material. Each dripline supplies water from drippers placed $0.20 \mathrm{~m}$ apart, with a total dripper flow rate of $0.85 \mathrm{~L} \mathrm{~h}^{-1}$. During irrigation, the water table $(\mathrm{pF}=0 ; \mathrm{pF}=\log \mid \mathrm{cm}$ $\mathrm{H}_{2} \mathrm{O} \mid$ ) is defined at the bottom of each tube controlled by the capillary flow by the polyester wick. A slope of $6.7 \%$ along the length of the facility ensure drainage of excess water.

A sensor system was installed within the soil profile and irrigation compartments. The sensor network consists of TDT volumetric water content (VWC) and temperature sensors (Acclima, Inc., Boise, ID, USA). Volumetric water content is determined following the factory calibration using the Topp equation [31]. VWC sensors were placed at two positions in the middle of 


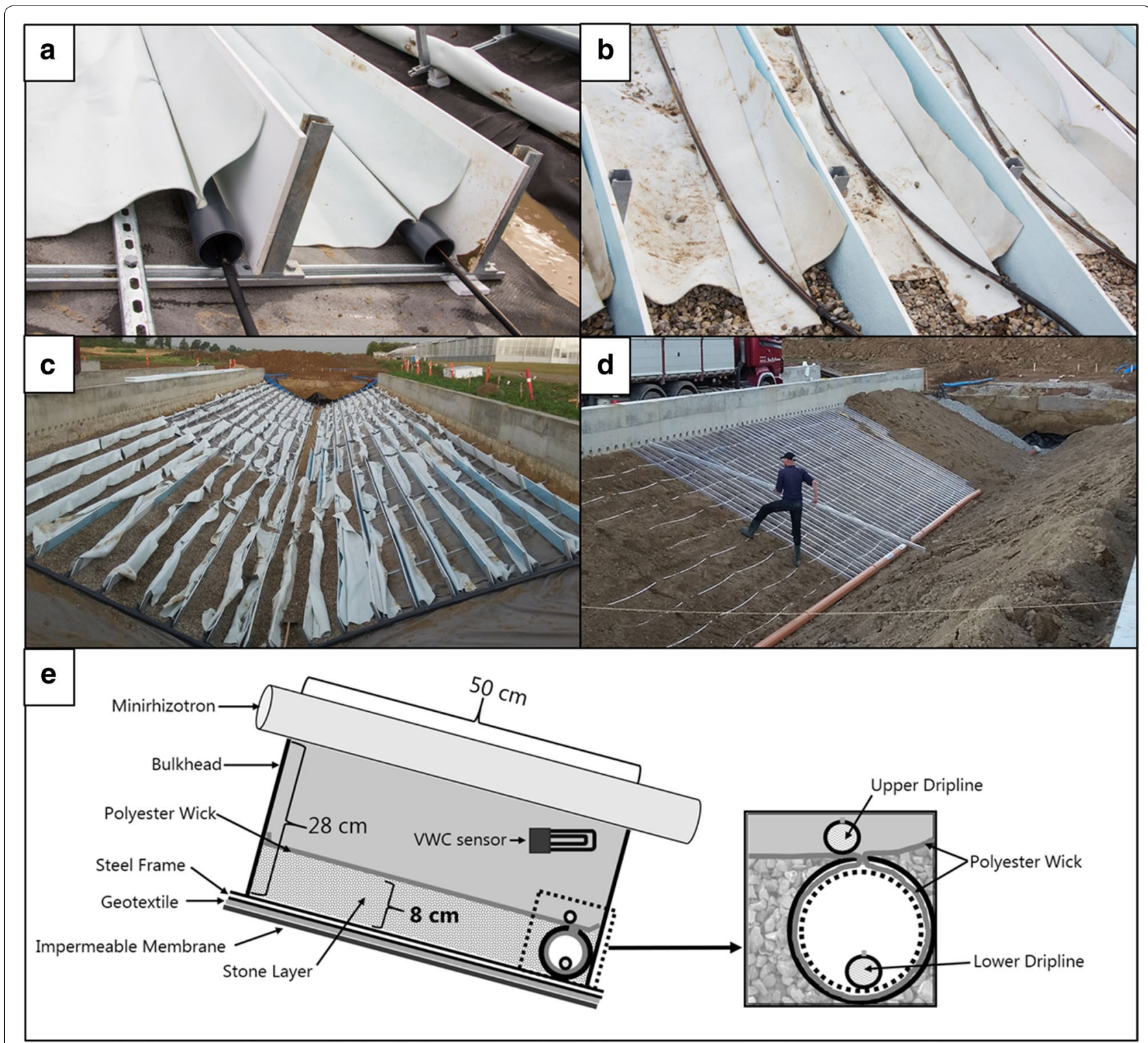

Fig. 3 Installation of the subsurface irrigation compartments and MR tubes. a Irrigation tube lined with wicking material supported by a steel frame skeleton. Lower driplines placed within the tube. b Irrigation tube fixed by stone fill with upper dripline installed before soil backfilling. $\mathbf{c}$ Overview of subsurface irrigation compartments during installation. $\mathbf{d}$ Installation of MR tubes after soil backfilling. e Schematic drawing of the subsurface irrigation compartments

each unit (West and East) at $0.5 \mathrm{~m}$ depth increments (Fig. 4). Furthermore, VWC sensors installed $0.25 \mathrm{~m}$ above the bottom provides a measurement within each irrigation compartment. Two CR6 data loggers (Campbell Scientific, INC., UT, USA) collect sensor data at 5 min intervals.

\section{Soil properties}

Two sandy loam soil mixes, a nutrient-rich topsoil mix and nutrient-poor subsoil mix, were prepared using locale soil resources (Table 1). The topsoil was excavated on-site from the A-horizon prior to construction. A subsoil mix was made from the $\mathrm{B}$ - and C-horizons $(0.5 \mathrm{~m}-2 \mathrm{~m})$ from a field located $12 \mathrm{~km}$ from the experimental farm, but of similar origin as the topsoil. The subsoil was excavated under dry conditions in August 2015, following a rapeseed crop. The top- and subsoil were mixed separately, and stones larger than $25 \mathrm{~mm}$ were removed by screening (Powerscreen Warrior, 1400). The soil mixes were carefully repacked into the four 


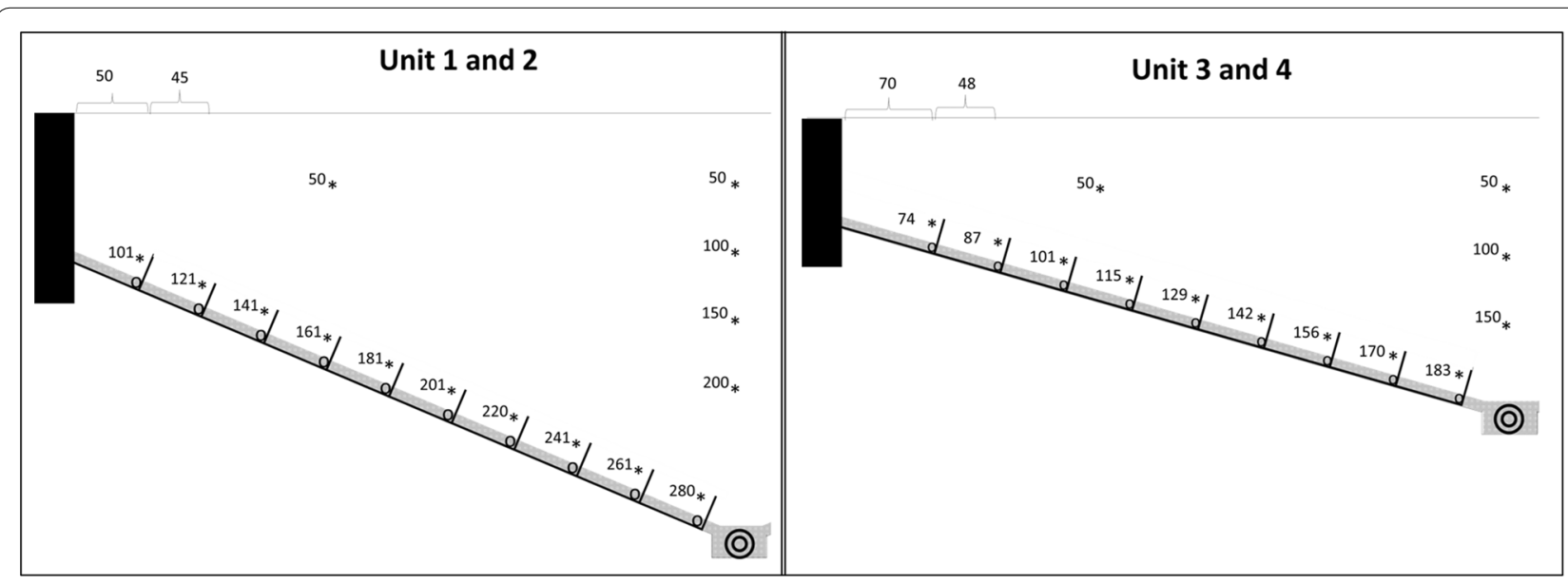

Fig. 4 Schematic illustration of the position of the volumetric water content sensors

Table 1 Soil texture of the fine soil fraction $(<2 \mathrm{~mm})$, mass fraction of gravel (2-25 mm), soil bulk density, field capacity (FC), permanent wilting point (PWP), porosity and chemical composition of the top and subsoil of the facility

\begin{tabular}{|c|c|c|c|c|c|c|}
\hline & Soil depth & $\begin{array}{l}\text { Clay } \\
<2 \text { ym }\end{array}$ & $\begin{array}{l}\text { Silt } \\
2-50 \text { ym }\end{array}$ & $\begin{array}{l}\text { Fine sand } \\
50-500 \text { ym }\end{array}$ & $\begin{array}{l}\text { Coarse sand } \\
500-2000 \text { ym }\end{array}$ & Organic matter \\
\hline & $m$ & & & $\%$ & & \\
\hline Topsoil & $0-0.4$ & $12.0(0.2)$ & $13.0(0.7)$ & $44.7(0.7)$ & $28.5(1.0)$ & $1.7(0.10)$ \\
\hline \multirow[t]{2}{*}{ Subsoil } & $0.5-1.0$ & $13.1(0.4)$ & $13.2(0.7)$ & $45.7(1.1)$ & $27.5(0.4)$ & $0.5(0.05)$ \\
\hline & $\begin{array}{l}\text { Soil depth } \\
\text { m }\end{array}$ & $\begin{array}{l}\text { Gravel } \\
\%\end{array}$ & $\begin{array}{l}\text { Bulk density } \\
\mathrm{g} \mathrm{cm}^{-3}\end{array}$ & FC & $\begin{array}{l}\text { PWP } \\
\text { vol\% }\end{array}$ & Porosity \\
\hline Topsoil & $0-0.4$ & 2.0 & $1.59(0.01)$ & 24 & 6 & 40 \\
\hline \multirow[t]{2}{*}{ Subsoil } & $0.5-1.0$ & 8.7 & $1.72(0.02)$ & 20 & 12 & 35 \\
\hline & $\begin{array}{l}\text { Soil depth } \\
\text { m }\end{array}$ & $P$ & $\begin{array}{l}\mathrm{K} \\
\mathrm{mg} \mathrm{kg}^{-1}\end{array}$ & $\mathrm{Mg}$ & $\mathrm{pH}_{(0.01 \mathrm{M} \mathrm{CaCl})}$ & \\
\hline Topsoil & $0-0.4$ & $3.8(0.2)$ & $11.1(0.9)$ & $5.1(0.1)$ & $7.0(0.04)$ & \\
\hline Subsoil & $0.5-1.0$ & $0.8(0.1)$ & $3.5(0.1)$ & $2.9(0.1)$ & $7.5(0.05)$ & \\
\hline
\end{tabular}

Mean value of the four units with standard error in brackets, $n=4$

units during periods of dry weather, one unit at a time, between August and October 2015. The soil was exposed to autumn and winter precipitation while it settled. 12 months later, a final $10 \mathrm{~cm}$ of topsoil was added, making the total topsoil depth $0.4 \mathrm{~m}$.

Soil samples were collected using a $1.5 \mathrm{~m}$ soil core sampler. Ten subsamples were collected from a cross-section at each end of the units and divided into two depth intervals $0-0.3 \mathrm{~m}$ and $0.5-1.0 \mathrm{~m}$. Soil particle size distribution of the fine soil $(<2 \mathrm{~mm})$ was measured by sieving and sedimentation following [32]. Soil Organic carbon, $\mathrm{pH}$ and the available content of $\mathrm{P}, \mathrm{Mg}$ and $\mathrm{K}$ were measured using plant available extraction methods that are standard in Denmark [33]. The mass fraction of gravel was measured in only one of the four units. In March 2017 the soil bulk density was measured by sampling of soil cores at $0.25 \mathrm{~m}$ and $0.7 \mathrm{~m}$ with two samples collected from each unit. Each sample consisted of 10 subsamples $(50 \mathrm{~mm}$ height, $50 \mathrm{~mm}$ diameter) and oven-dried to a constant weight at $105^{\circ} \mathrm{C}$. The soil physical properties were measured In-situ by sensors installed within the repacked soil matrix (see Additional file 1). Detailed measurements of soil texture of the fine soil, bulk density and chemical composition within each unit are available (Additional file 2).

\section{Experimental design and measurements}

Selections of European spring barley (Hordeum vulgare L.) lines were grown in two seasons in a complete randomized block design. The majority of these are modern breeding lines. However, to allow for replicated 
measurement over the two seasons, seven marketed cultivars were selected on the basis of shoot morphological characteristics and year of release. Three of these (Laurikka, Invictus and Evergreen) are modern cultivars characterized by high yield in conventional crop production in northern Europe, while a fourth, Evelina, is aimed for organic growth conditions in central Europe. The remaining cultivars (Tocada, Prisma, and Kenia) were selected because previous work shows contracting differences in NUE [34].

The spring barley lines were seeded in rows perpendicular to the center aisle and directly on top of the MR tubes below, giving a $25 \mathrm{~cm}$ row distance. Dates and details for crop establishment, management and sampling are presented in Table 2. In 2016, 59 lines were grown in two replicated rows in unit 3, while the 2017 experiment had 74 lines grown in four replicated rows within units 1 and 2 . Data of Grain yield and protein content was gathered for all cultivars in both seasons. At harvest, each row was divided into four subsamples: two from the deep mid-section $\left(\mathrm{area}_{2016}=2.23 \mathrm{~m} \times 0.25 \mathrm{~m}\right.$, area $\left._{2017}=2.13 \mathrm{~m} \times 0.25 \mathrm{~m}\right)$ and two from the border section $\left(\right.$ area $_{2016}=2.13 \mathrm{~m} \times 0.25 \mathrm{~m}$, area $_{2017}=1.93 \mathrm{~m} \times 0.25 \mathrm{~m}$ ) of each unit. The outermost $0.5 \mathrm{~m}$ was defined as border and removed before harvest. At harvest, ears were collected, dried to constant weight, threshed and weighed. Grain protein content and water content was determined by near-infrared transmission measurement (Intratec grain analyzer, Foss, Hilleroed, Denmark). Grain nitrogen content was estimated on the basis of the grain protein content using 6.25 as the conversion factor for barley [35].

\section{Table 2 Overview of the two experiments}

\begin{tabular}{|c|c|c|}
\hline Treatment & Exp. 1 & Exp. 2 \\
\hline Unit & 3 & 1 and 2 \\
\hline Previous crop & Rye (cover crop) & $\begin{array}{l}\text { Wheat/grass } \\
\qquad(+ \text { cover crop) }\end{array}$ \\
\hline Plowing & 23.03 .16 & 20.12 .16 \\
\hline Cultivars & $59(n=2)$ & $76(n=4)$ \\
\hline Cultivars test experiment (rows) & $7(n=4)$ & $7(n=4)$ \\
\hline Seeding date & 12.04 .16 & 28.03 .17 \\
\hline Seeding density (seeds m²) & 300 & 300 \\
\hline Fertilizer date & 12.04 .16 & 28.03 .17 \\
\hline $\begin{array}{l}\text { Fertilizer application rate }(\mathrm{kg} \mathrm{N} \\
\mathrm{ha}^{-1} \text { ) }\end{array}$ & 70 & 100 \\
\hline Root imaging & 03.06.16/28.06.16 & 05.06.17/23.06.17 \\
\hline Day of flowering (anthesis) & $\approx 13.06 .16$ & $\approx 14.06 .17$ \\
\hline Rainout shelter deployed & 15.06 .16 & 07.06 .17 \\
\hline Harvest & 02.08 .16 & 03.08 .17 \\
\hline
\end{tabular}

The seven marketed cultivars were grown in both seasons in four replicated rows. For these rows, data of grain yield and protein were supplemented with measurement of total nitrogen content and ${ }^{13} \mathrm{C}$ enrichment (2017 only), but only for half of the row (the part of the row that contained MR tubes (i.e., from the concrete aisle to the centerline, see Fig. 2). Samples consisting of one ear sampled from each of eight different plants were taken from four positions $(1 \mathrm{~m}$ intervals starting $0.5 \mathrm{~m}$ from the border). The samples were dried at $75{ }^{\circ} \mathrm{C}$ for $48 \mathrm{~h}$, weighed, milled, before total carbon, nitrogen and ${ }^{13} \mathrm{C}$ were measured using a PDZ Europa ANCA-GSL elemental analyzer interfaced to a PDZ Europa 20-20 isotope ratio mass spectrometer (Sercon Ltd., Cheshire, UK).

Agrometeorological data were acquired from a weather station located 600 meters west of the facility. Reference Evapotranspiration $\left(\mathrm{ET}_{\mathrm{o}}\right.$ ) was calculated hourly by the FAO-Penman-Montieth method using measured data of Air Temperature $(Z=2)$, Air humidity $(Z=2)$, Wind $(Z=2)$, Net Radiation $(Z=2)$ and Soil Heat Flux $(Z=-0.05)$, where $Z$ is height in meters in relation to an extensive surrounding surface of well-watered green grass [36]. Precipitation of rain and snow was measured hourly at $1.5 \mathrm{~m}$ and adjusted for wind effects [37]. The Makkink-Hansen estimation model was used to compare reference evapotranspiration with long-term on-site data [38]. A water balance simulation was made for each experiments using a plant and soil model DAISY and the agrometeorological data (For parametrisation of water balance model, see Additional file 1). Compartmentalized subsurface irrigation, intended to keep VWC above a threshold target of $20 \%(\mathrm{pF}=1.8)$, was initiated when the VWC sensors detected root water uptake within a compartment.

\section{Root measurements}

Root imaging was conducted twice in each season at heading and at late anthesis (flowering). The root data presented in this paper were collected using RGB images following a grid intersection procedure [7]. Briefly, Images were collected for every $10 \mathrm{~cm}$ in 2016 and $5 \mathrm{~cm}$ in 2017 within the tube. The respective soil depth of each image was calculated as $\sin$ (horizontal angle in degrees) $\times$ tube depth + start depth. Each image covered an area of $0.05 \times 0.035 \mathrm{~m}$ of the upper surface of the MR tubes and its interface with the soil. To determine the number of root intersections, a counting grid with a total line length of $0.33 \mathrm{~m}$ was superimposed on the image. In the second season, only white living root structures were recorded in order to avoid including still-visible root residue from the previous crop. The values were standardized as root intensity expressed as the sum of counts per $\mathrm{m}$ of gridline. Root intensity was averaged per $0.25 \mathrm{~m}$ 


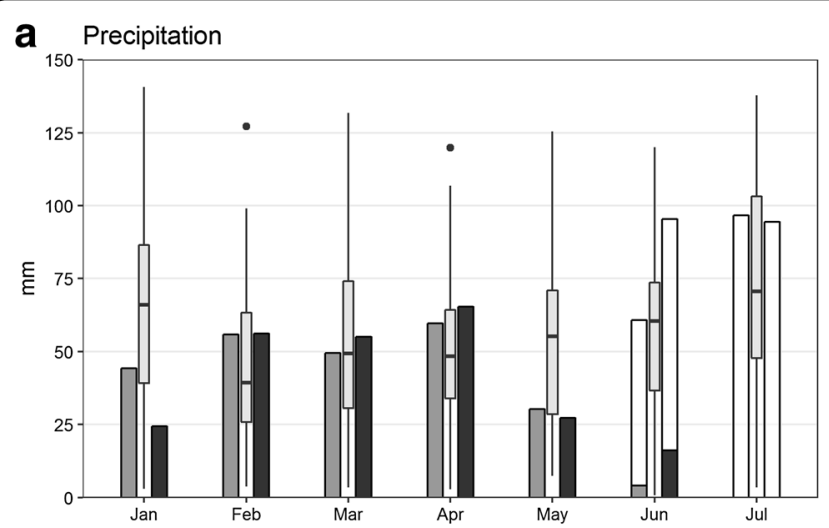

C Air Temperature

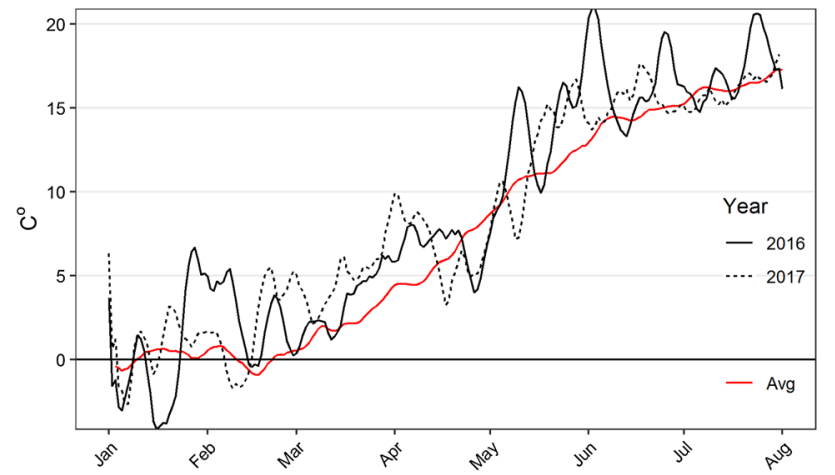

b Evapotranspiration (ETo Makkink Hansen)

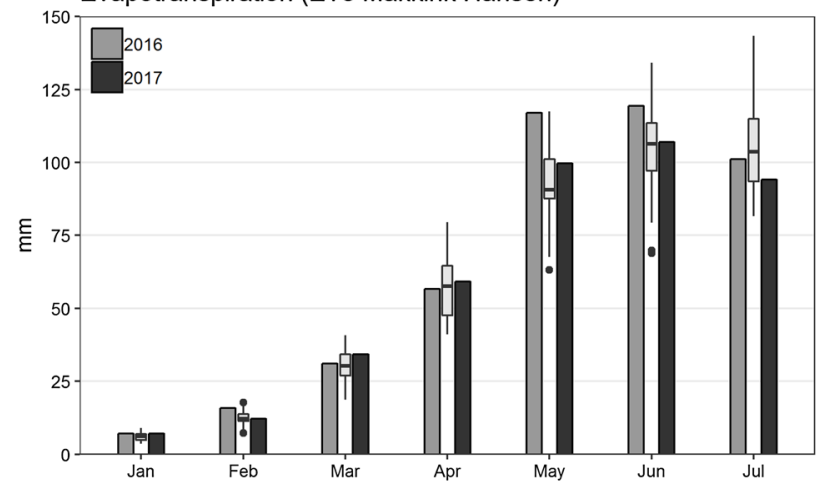

d Soil Temperature $50 \mathrm{~cm}$

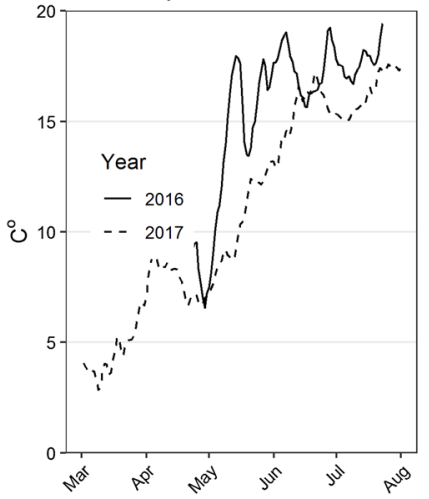

Soil Temperature $100 \mathrm{~cm}$

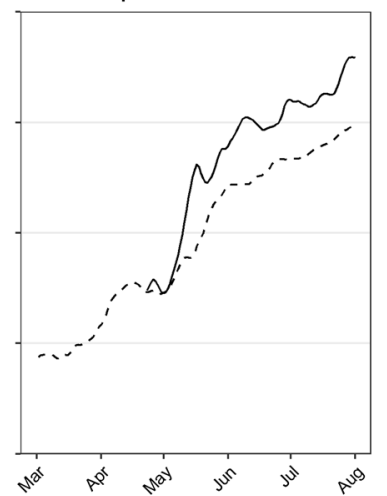

Fig. 5 Weather data for two seasons of spring barley experiments. a Grey bars show the actual precipitation falling on the experiments, while white open bars in June and July indicate potential precipitation if rainout shelters had not been used. $\mathbf{b}$ Estimated reference evapotranspiration (Makkink-Hansen evapotranspiration estimates). $\mathbf{a}$ and $\mathbf{b}$ Solid bars show experimental data in both seasons, while boxplots relate to seasonal averages data from 1962 to 2008. Boxes show first quartile, median and third quartile. Extreme values are shown as points, while whiskers extend to the most extreme value within $1.5 \times$ box length. $\mathbf{c}$ Lines represent daily air temperature as a 5-day moving average with the seasonal daily averages shown as a solid red line. $\mathbf{d}$ Daily soil temperature ( $0.5 \mathrm{~m}$ soil depth and $1.0 \mathrm{~m}$ soil depth)

of soil depth interval to represent the average root intensity at each depth and date in both seasons. For statistical analysis of differences between cultivars, deep root intensity was defined as the total number of intersections observed below $0.9 \mathrm{~cm}$ soil depth.

\section{Data analysis}

The effect of position and cultivar on aboveground biomass measurements was tested using a TWO-WAY linear model with generalized least square (GLS), including errors in a Gaussian correlation structure based on the position in each unit $(\mathrm{x}, \mathrm{y})$. A similar model was used to test the effect of cultivar on deep root intensity. Here, the correlation structure was made in one direction based on the tube number. All tests were made using the nlme package in the software $R$ [39]. For 2017 data, the effect of the unit was tested as a TWO-WAY Anova, including cultivar as fixed effect (Additional file 3). Estimated means of position and cultivars was determined using the emmeans package in $\mathrm{R}[40]$.

\section{Results}

\section{Weather and growth conditions}

Both seasons were warmer than average, except for a cold period in late April (Fig. 5). May and June 2016 were exceptionally sunny, with two warm peaks in early and late May leading to a rapid increase in soil temperature and evapotranspiration (Fig. 5). Average levels of precipitation were measured in March and April, while May experienced dry conditions ( $<25 \mathrm{~mm}$ precipitation) in both seasons. During the period from 1 February until the onset of the drought treatment by rainout shelters in June the precipitation was similar in the 2 years $(2016 ; 199 \mathrm{~mm}$, $2017 ; 220 \mathrm{~mm}$ ). However, slight differences in rainfall pattern and drainage flow, combined with greater evapotranspiration rates in 2016, made the water deficit by early June $50 \mathrm{~mm}$ larger compared to 2017 when drainage and potential evapotranspiration $\left(\mathrm{ET}_{\mathrm{c}}\right.$ ) was simulated (Fig. 6). In both seasons, the water balance model indicates that precipitation in late April caused drainage of excess soil water to continue until early May, which is consistent with 

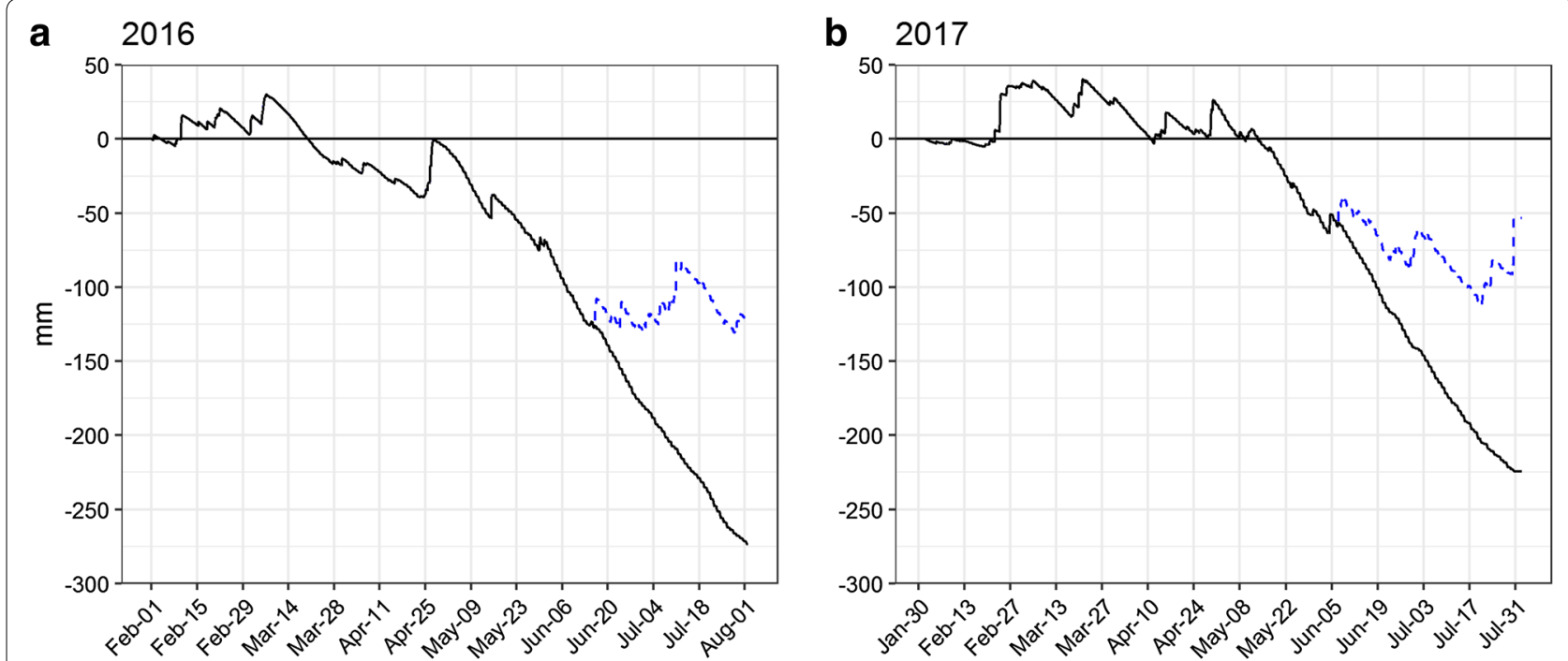

Fig. 6 Simulated water balance of two spring barley experiments conducted in 2016 (a) and 2017 (b). The model was parameterised with the soil physical data from the topsoil $(0 \mathrm{~m}-0.4 \mathrm{~m}$ ) and subsoil $(0.4 \mathrm{~m}-2 \mathrm{~m}$ ) (solid black line). Spring barley managed as described in Table 2 with simulated drainage and potential evapotranspiration (see Additional file 1). The blue dashed line represents the water balance if no drought had been induced by rainout shelters

an observed peak seen for all soil water content sensors at $150 \mathrm{~cm}$ at this time point in both seasons (Fig. 7).

\section{Soil moisture measurements}

The VWC sensors provided a precise measure of soil moisture with limited sensor-to-sensor variation, returning a high degree of precision having a low standard error (Fig. 7a, c). The data collected from the VWC sensor network yielded valuable information as to how water was depleted from the soil by the growing barley crop. In both seasons, the soil layer around $0.5 \mathrm{~m}$ experienced dry conditions $(\mathrm{pF}>3.0 \approx \mathrm{vol} \%<15.3)$ from the beginning of June and soil water was rapidly depleted from the layer (Fig. 7a, c). Overall, more water was used in the 2016 season with a higher uptake even at $1.5 \mathrm{~m}$ than in 2017. In addition, soil water depletion at $1 \mathrm{~m}$ occurred approximately 3 weeks later in 2017 than in 2016, but in both seasons the soil ultimately reached the dry range of the retention curve. Importantly, subsurface irrigation by capillary rise was sufficient to keep the soil water content above $20 \%$ within the lowest irrigation compartments along the sloping bottom (see Fig. 7b, d), although soil in the midsection became dry below $1 \mathrm{~m}$.

The experiments in 2016 were made in unit 3, and 2017 experiment was conducted in the deepest units 1 and 2. Consequently, the depths and slope angle of the subsurface irrigation compartments are different and not directly comparable. However, in 2016 a decline in soil water content were observed down to the deepest irrigation compartment at $1.83 \mathrm{~m}$. In contrast, only the four upper sub-irrigation compartments showed signs of significant water depletion in 2017 (down to $1.61 \mathrm{~m}$ ). In 2016, driplines were left running for long intervals that were followed by longer drying periods, leading to larger fluxes in soil water content. In 2017, subsurface water was emitted by a daily irrigation sequence of ten 5 - $\mathrm{min}$ pulses over $10 \mathrm{~h}$. The new irrigation strategy in 2017 resulted in more stable soil water content readings by the subsurface irrigation sensors (Fig. 7d).

\section{Root growth and development}

Roots grew deeper in the 2016 season than in 2017 (Fig. 8), which is consistent with a stronger decline of soil water at $1.5 \mathrm{~m}$ in 2016 (Fig. 8). Despite the high variation within MR data, significant differences among cultivars were found in both seasons (Fig. 9). Kenia and Laurikka consistently had fewer deep roots than Tocada and Prisma. A two-way ANOVA revealed a significant difference between the two units in the 2017 season (Additional file 3). Consequently, unit effects were included in the statistical model of the 2017 season.

\section{Effect of drought and subsurface irrigation on plant growth}

Despite the dry conditions during anthesis and grain filling, the spring barley grain yield were only slightly reduced compared to regional average yield levels in both seasons. A low but significant effect of position 


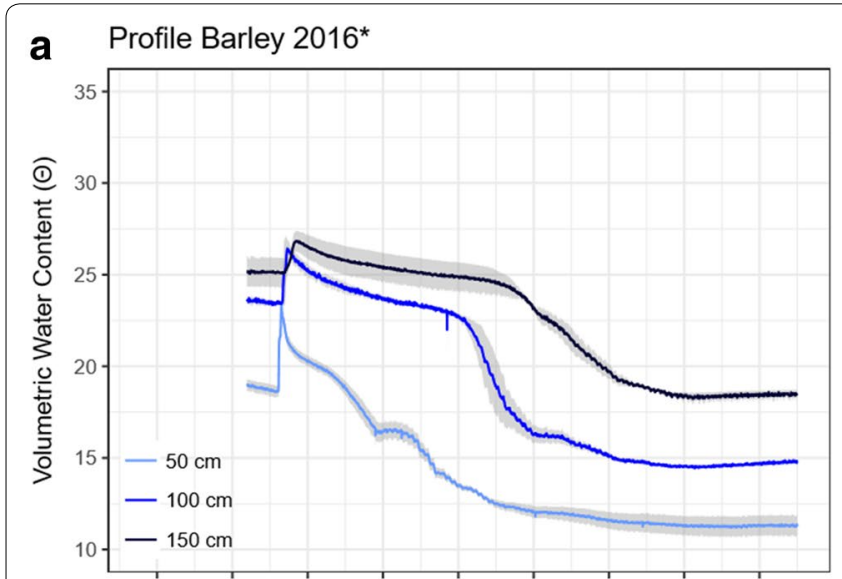

b Subsurface Barley 2016
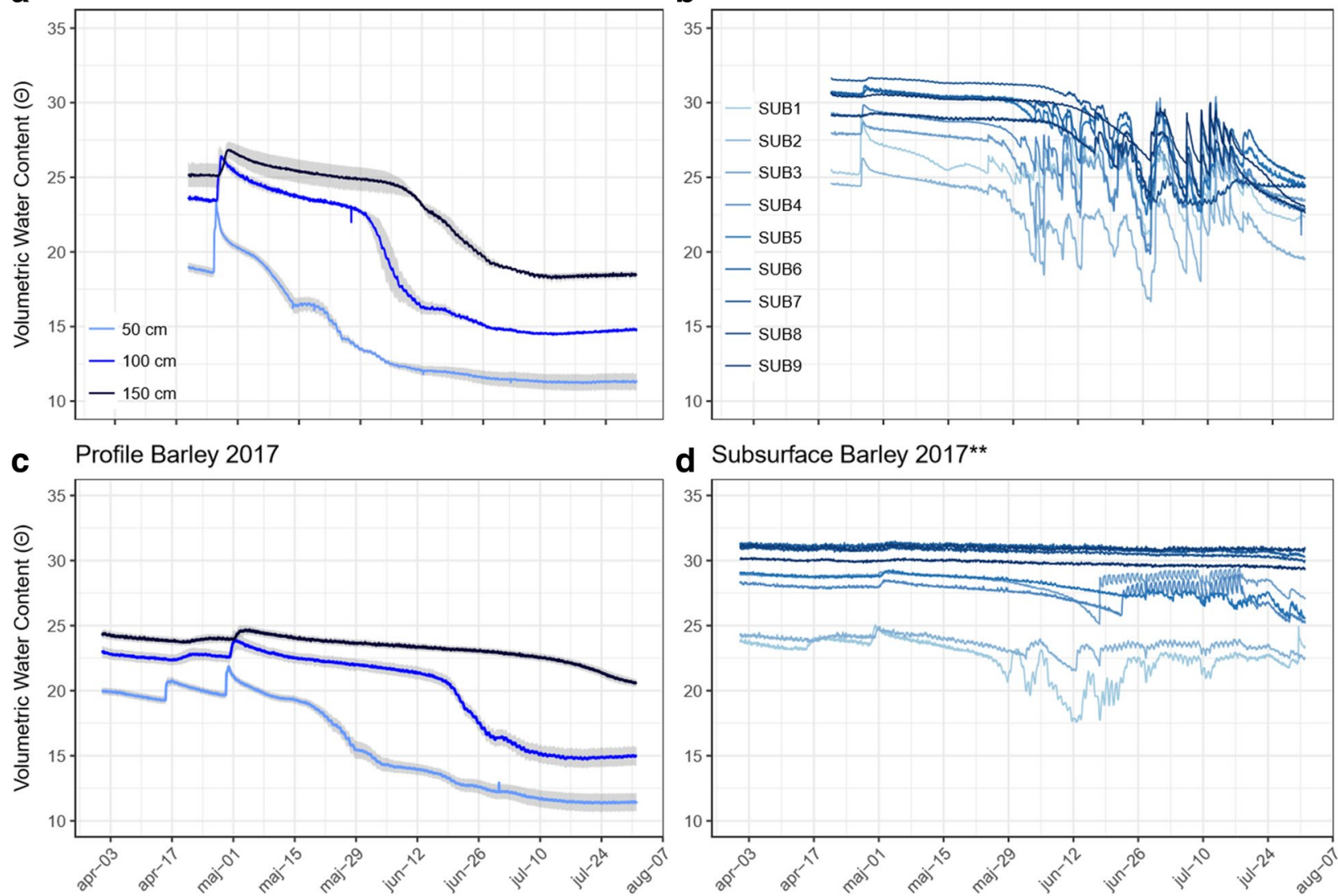

d Subsurface Barley $2017^{* *}$

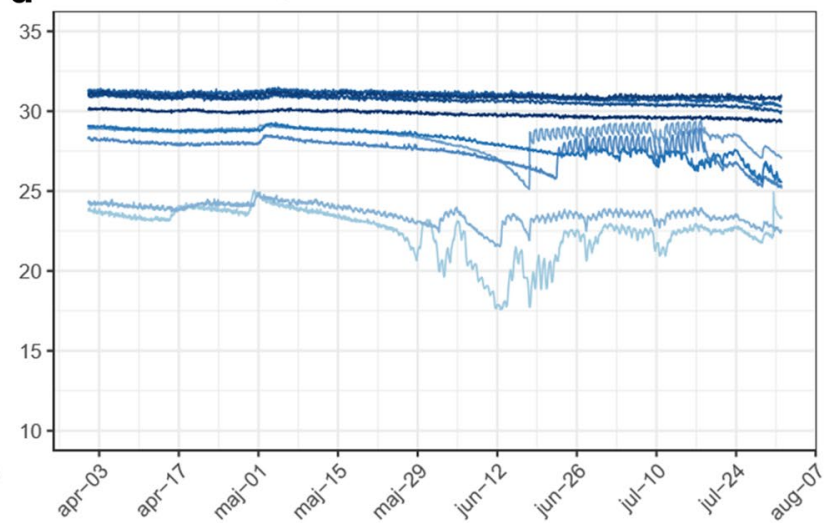

Fig. 7 Volumetric water content (VWC) measurements from two experiments of spring barley. The subplots to the left (a, c) represent the mean VWC of three soil layers in the middle of each bed and the corresponding standard error, shown as a blue shade $\left(n_{50 \mathrm{~cm}}=8, n_{100 \mathrm{~cm}}=4, n_{150 \mathrm{~cm}}=4\right)$. Subplots $\mathbf{b}$ and $\mathbf{d}$ show VWC data from the 9 subsurface irrigation compartments from the top section (SUB1, light blue) to the bottom section (SUB9, dark blue). ${ }^{*}$ The 2016 experiment was made in one unit only $\left(n_{50 \mathrm{~cm}}=4, n_{100 \mathrm{~cm}}=2, n_{150 \mathrm{~cm}}=2\right)$. ${ }^{* *}$ The 2017 experiment was made in units 1 and 2, while the 2016 experiments were made in unit 3 . The depths and slope angle of the subsurface irrigation compartments are different

on grain yield were seen in both seasons, with the highest yield level seen in the border section (Table 3). Also, a strong significant position effect was found for kernel size in both seasons, with kernels in the midsection being smaller than the border section. Grain in the midsection contained more protein in both seasons, but grain yield and estimated grain nitrogen removal ( $\mathrm{N}$-grain) was higher in the 2017 season than in the 2016 season.

Furthermore, a larger reduction in grain-yield and $\mathrm{N}$-grain was observed in the 2016 season. In both seasons and for all aboveground parameters, the strong significant cultivar effect shows that it was possible to detect cultivar differences despite using a rather small sample size in the facility compared to the plot size normally used in field experiments. Other methods to detect the water stress gradient were tested in the 2017 season (Fig. 11). A visible increase in leaf temperature in the midsection was observed during the early grain filling using an airborne thermal camera. Similarly, a significant change in the carbon isotope discrimination ratio was found when comparing samples from the border section to the midsection.

\section{Discussion}

\section{The minirhizotron phenotyping system}

During construction of the facility, several measures were taken to improve the root phenotyping data delivered by MR-imaging. All 600 tubes were successfully installed during dry conditions, thus preventing mud smearing of the tube surface. In addition, since the MR tubes were not pushed into predrilled boreholes with tight soil connections, scratching along the tube surface was reduced. Furthermore, in contrast to field conditions where MR tubes are often installed with a slope angle greater than $45^{\circ}[41,42]$, our MR tubes were installed at an angle closer to horizontal $\left(15.8^{\circ}-23.5^{\circ}\right)$. The low slope angle not only reduces the risk of roots growing downwards along the tube surface, but also provides a larger observation area per unit of soil depth covered. Finally, 

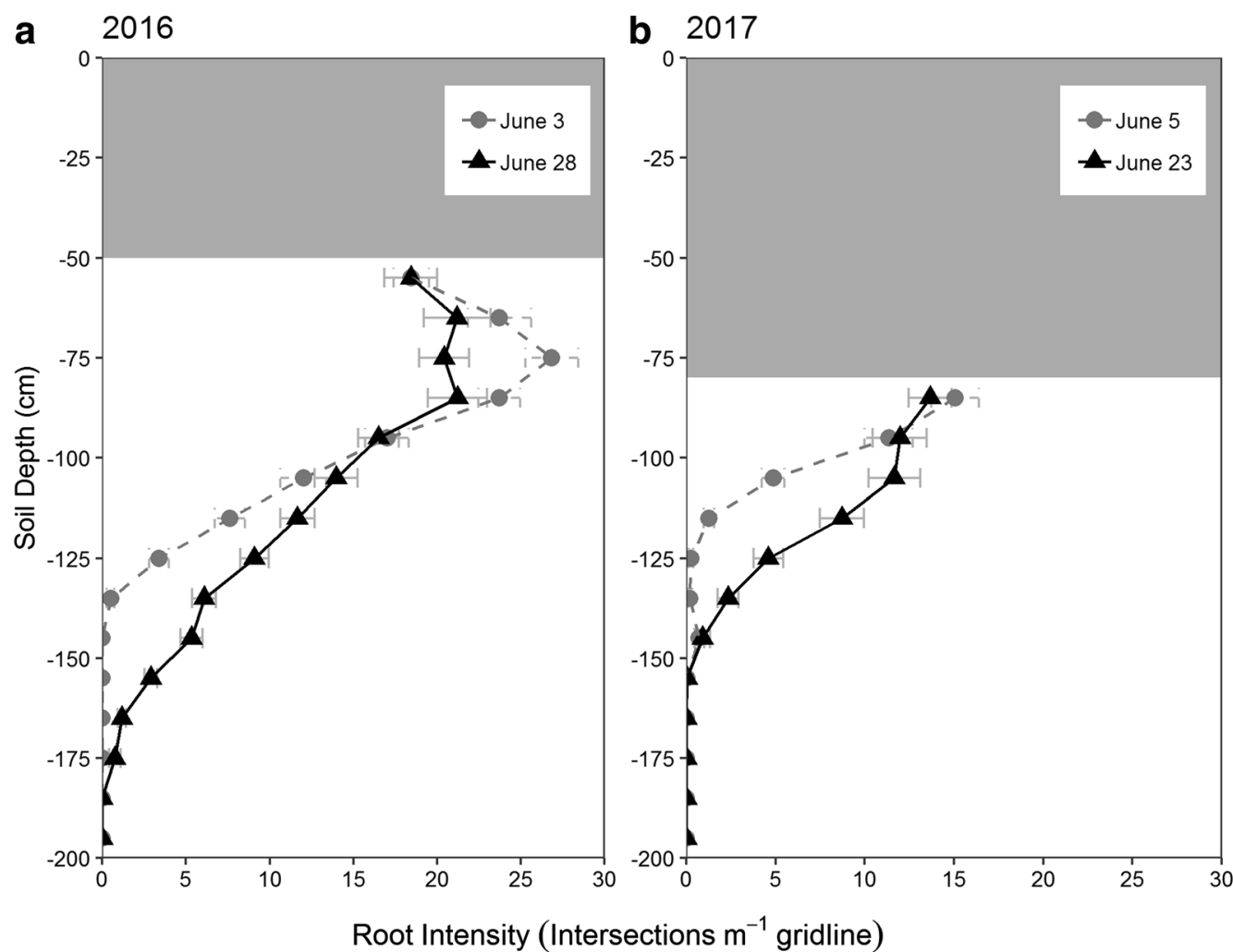

Fig. 8 Depth distribution of root intensity. The figure shows the overall root intensity determined in $0.1 \mathrm{~m}$ increments for the two experiments of spring barley in 2016 (a) and 2017 (b) (mean \pm standard error $n=28$ ). Grey shaded areas in the top of the plot indicate soil layers not covered by the MR tubes. The experiment was conducted in units 1 and 2 in 2017, with root observations starting at $80 \mathrm{~cm}$ versus $50 \mathrm{~cm}$ for unit 3 in 2016
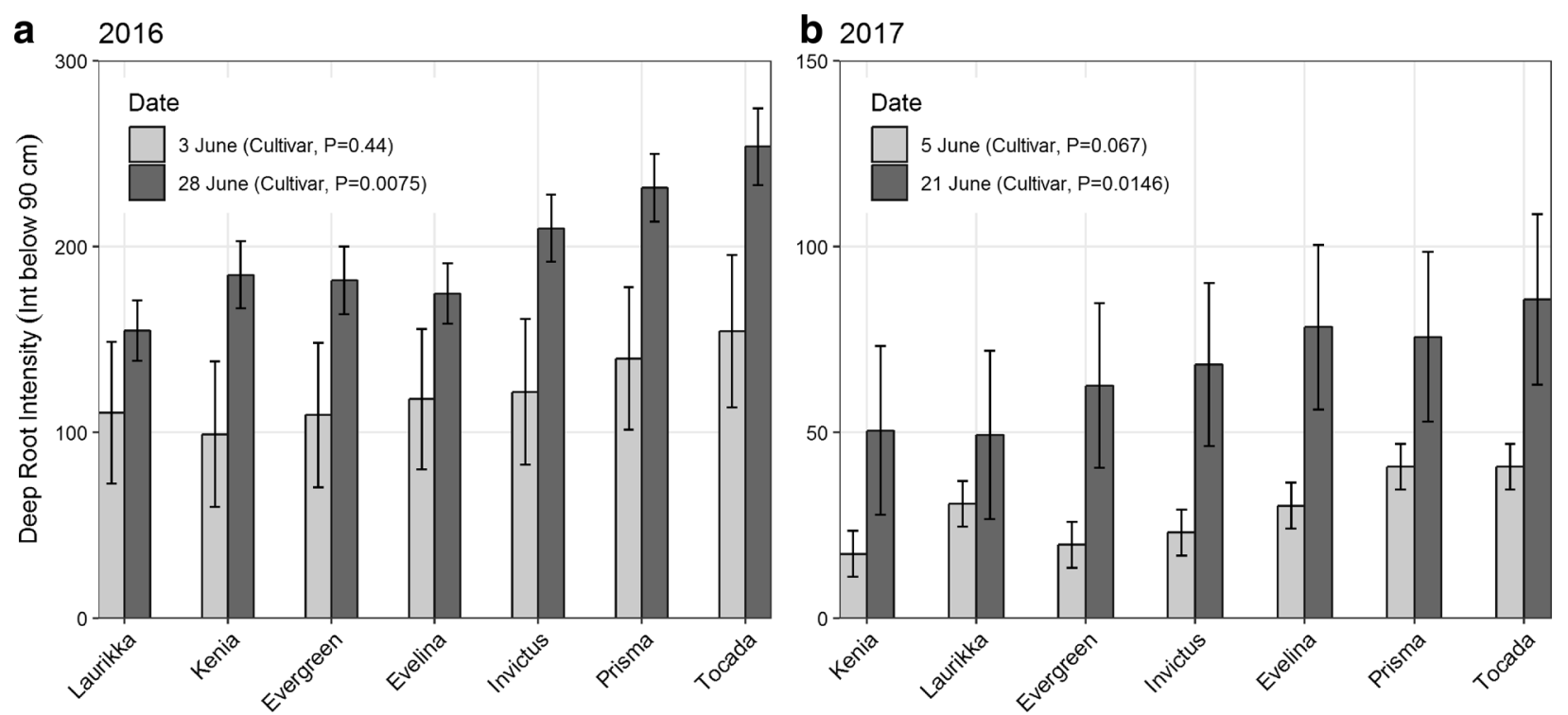

Fig. 9 Deep root intensity of seven spring barley cultivars in the 2016 and 2017 seasons $(\mathbf{a}, \mathbf{b})$. Estimated mean and standard error $n=4$. P values for cultivar effect in figure legend (one-way ANOVA.GLS model) 
Table 3 Comparison of the harvest samples of spring barley cultivars from the border and midsection of each unit in two seasons

\begin{tabular}{|c|c|c|c|c|c|c|c|c|}
\hline & \multicolumn{2}{|l|}{ Grain yield } & \multicolumn{2}{|l|}{ TKW } & \multicolumn{2}{|l|}{ Protein } & \multicolumn{2}{|l|}{$\mathrm{N}$ grain } \\
\hline & \multicolumn{2}{|l|}{$\mathrm{Mg} \mathrm{ha}^{-1}$} & \multicolumn{2}{|l|}{ g } & \multicolumn{2}{|l|}{$\%$} & \multicolumn{2}{|l|}{$\mathrm{kg} \mathrm{N} \mathrm{ha}^{-1}$} \\
\hline & Border & Mid & Border & Mid & Border & Mid & Border & Mid \\
\hline 2016 & $6.03(0.05)$ & $5.56(0.05)$ & $52.0(0.14)$ & $51.0(0.14)$ & $7.9(0.06)$ & $8.10(0.07)$ & $74.9(2.1)$ & $70.6(1.72)$ \\
\hline Position & $P<0.0001$ & & $P<0.0001$ & & $P=0.044$ & & $P=0.0029$ & \\
\hline Cultivar & $P<0.0001$ & & $P<0.0001$ & & $P<0.0001$ & & $P<0.0001$ & \\
\hline Position $\times$ cultivar & $n s ; P=0.32$ & & $n s ; P=0.98$ & & $n s, P=0.40$ & & $n s ; P=0.26$ & \\
\hline 2017 & $7.22(0.07)$ & $6.98(0.08)$ & $53.6(0.33)$ & $52.6(0.42)$ & $9.30(0.08)$ & $9.60(0.09)$ & $107.5(1.77)$ & $107.3(2.09)$ \\
\hline Position & $P=0.0081$ & & $P=0.0034$ & & $P=0.0044$ & & $\mathrm{~ns}, \mathrm{P}=0.95$ & \\
\hline Cultivar & $P<0.0001$ & & $P<0.0001$ & & $P<0.0001$ & & $P<0.0001$ & \\
\hline Position $\times$ cultivar & $n s ; P=0.43$ & & $\mathrm{~ns} ; \mathrm{P}=0.89$ & & $n s ; P=0.12$ & & $n s ; P=0.50$ & \\
\hline
\end{tabular}

Estimated means, standard error (in brackets) and P values from the corresponding two-way ANOVA output, $(n(2016)=4 \times 59 ; n(2017)=8 \times 79)$. Grain yield, thousand kernel weight (TKW), protein content (Protein \%) and estimated grain nitrogen removal ( $\mathrm{N}$ grain)

the careful installation procedure resulted in a homogenous soil background, which improves the root quantifications by eye or by automated image analysis (Fig. 10).

Of special concern was the risk of identifying old roots from the previous season, as the MR tubes are installed permanently. To account for this challenge, a multispectral imaging system inspired by [43] was developed. The system uses a portable trolley system and four multispectral camera systems, thus allowing for multivariate image analysis using five wavebands $(405 \mathrm{~nm}, 450 \mathrm{~nm}, 590 \mathrm{~nm}$, $660 \mathrm{~nm}, 940 \mathrm{~nm}$ ) (Fig. 10). Using multivariate grouping of pixels based on differences in reflectance and by suppression background noise by a vesselness enhancement filter automated detection were possible (S.F. Svane, E. B. Dam, J. M. Carstensen and K. Thorup-Kristensen, unpublished observation). Since the facility contains a total of 600 MR tubes corresponding to $\approx 95,000$ images per imaging campaign, traditional manual root quantification from individual RGB images would be time-demanding. The potential time savings of automated image analysis for root quantification was therefore critical for the full exploitation of the facility. Nonetheless, the root quantification presented in this paper was performed by the manual grid intersection procedure since the multispectral imaging system was not available in the 2016 season.

\section{Minirhizotron root observations}

Although having only a short growing period, the spring barley crop developed a deep root system, extending to soil layers below $1 \mathrm{~m}$. Roots extending below $1 \mathrm{~m}$ is deep for spring barley, but have been observed in the field both by MR imaging and soil coring under similar soil and climate conditions [44, 45]. Interestingly, large seasonal differences were present, with both deeper roots and greater

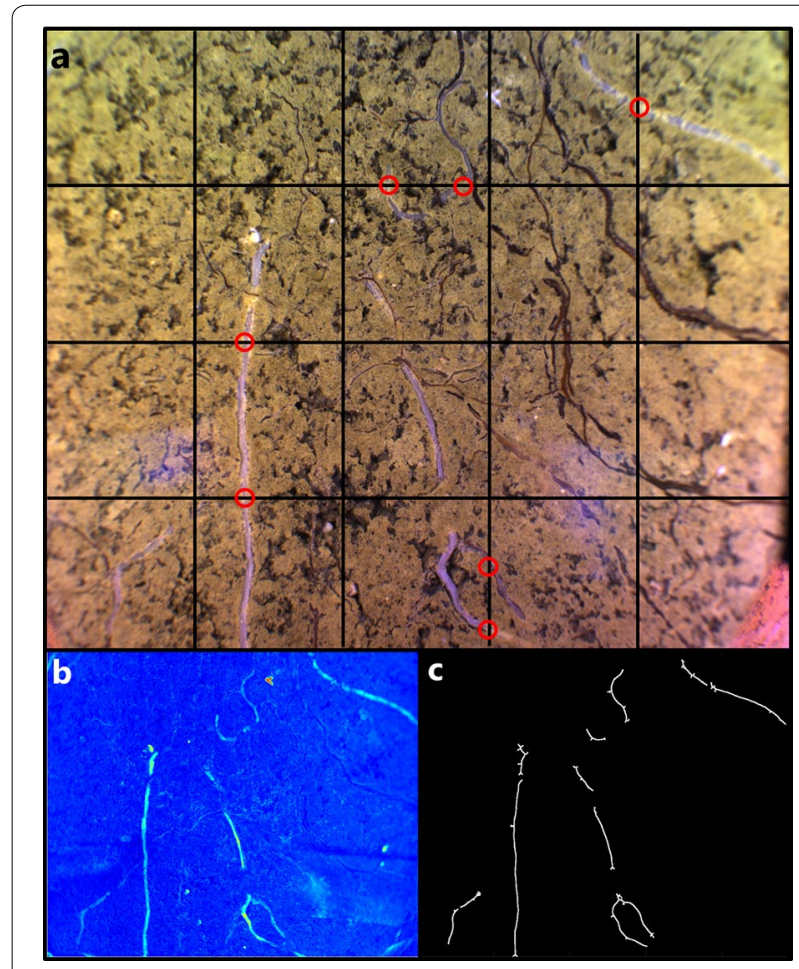

Fig. 10 Minirhizotron root image of spring barley roots appearing with the presence of dead roots of red fescue with root length quantified by grid counting and by automated multispectral image analysis. a RGB type image with a grid structure applied for root quantification as performed in this study. Manual observers counted the number of times living white spring barley roots intersected with superimposed gridlines (red circles). b Transformed image using normalized canonical discriminant analysis (nCDA) c Final centerline extracted root length after noise removal using a vesselness enhancement filter 
root intensity in the 2016 season. Many factors within the soil environment could contribute to such differences. Soil texture, soil structural and climatological conditions such as rainfall pattern are known to have a large impact on the development of deep roots in the field [44]. Furthermore, low subsoil temperature is known to limit the root elongation rate [46, 47]. Differences in soil compaction level may also account for the observed year-toyear effect $[48,49]$ and finally seasonal differences in soil nitrogen level could influence the lateral root elongation rate [50-52]. Of the factors listed, measurements of soil temperature were available and revealed large differences in soil temperature between 2016 and 2017. An increase of soil temperature from 7 to $13{ }^{\circ} \mathrm{C}$ at $0.5 \mathrm{~m}$ depth, as observed between May 2017 and May 2016, has been found to increase the rate of root extension by $\approx 100 \%$ and the dry root weight of barley by $192 \%$ [47]. Measurements of soil bulk density and vertical distribution of soil nitrogen were not taken in 2017. However, it is likely that the soil was more compact and less nitrogen was present than in the 2016 season, the first year after construction. If so, these factors might also have contributed to the inter-year variation in root development.

Despite the observed seasonal differences in root development, a statistically significant effect of cultivar on deep root intensity was demonstrated. The cultivars Tocada and Prisma produced more roots in the deep soil layers in both years, and the ranking of deep root intensity of the seven cultivars was almost identical from 1 year to the next. However, no statistically significant differences among the cultivars were found in the early June comparisons of the 2 years, likely because of the low root counts in the early imaging interval decreasing the precision of the measurements.

Although significant cultivar differences were identified, the observed decrease in precision of the 2017 data may be explained by the observed block effect between units 1 and 2 (Additional file 3), which may be inferred from different pre-crops between unit 1 (wheat) and unit 2 (grass), leading to a difference in soil nitrogen levels. Such differences will be avoided by appropriate longterm planning in future studies within the facility.

Finally, the system was designed under the expectation that a distance between the MR tubes of $0.25 \mathrm{~m}$ is sufficient to exclude roots from neighboring rows. Currently the scale of this a potential neighbor effect is not known but a recent study have been made as an attempt to quantify the error (S. Chen, S.F. Svane and K. Thorup-Kristensen, unpublished observation). Here, water with ${ }^{15} \mathrm{~N}$ tracer was emitted along $15 \mathrm{MR}$ tubes by pressure-compensated driplines. The tracer was only emitted along every second row and MR tube, which enabled investigation of ${ }^{15} \mathrm{~N}$ uptake by plants in unlabeled neighbor rows.
It was found that plants in these neighboring rows contained only $10-25 \%$ of the ${ }^{15} \mathrm{~N}$ level found in target-row plants. As ${ }^{15} \mathrm{~N}$ will spread from the emission points, roots from neighbor rows can take up some ${ }^{15} \mathrm{~N}$ without growing all the way to the emission point. One way to more accurately determine the error term in a future study would be to MR-image plant lines with roots expressing a green fluorescent protein [53]. Despite the potential neighbor effect, a statistical significant cultivar effect was found in both seasons.

\section{Managing the water stress gradient}

The control of a permanent water stress gradient using rainout shelters combined with a multi-depth subsurface irrigation system is a central part of the infrastructure. The subsurface irrigation system is designed to use the process of capillary rise to distribute water within each irrigation compartment. However, to accurately manage the water stress gradient it is important to know at which depth water uptake occurs. Information about the depth distribution of root water depletion is provided to some extent by MR imaging, and potentially provided by more advanced full-system crop models including a root growth model, e.g. $[54,55]$. However, direct measurement of soil water by the VWC sensors is important in the daily management of the water stress gradient, as it allowed the startup of subsurface irrigation only when needed and thus saved unnecessary pumping activity in periods with no demand. The VWC sensors offered stable and precise measurements of soil water content. Low sensor-sensor variation, including similarly shaped curves during soil drying, indicates a similar porosity and soil texture within and between the units. This finding is supported by the low variation in soil texture and bulk density found by analyzing samples from auguring and soil coring between and within the units (Table 2 and Additional file 2).

The design with the sloping bottom combined with subsurface irrigation might risk horizontal water flow between the subsurface irrigation compartments. If present, the horizontal flow could transport nitrate- $\mathrm{N}$ from the border towards the midsection [56]. This effect would affect the interpretation of the stress symptoms in the aboveground leaves and the sampled biomass data, so bulkheads were installed to prevent horizontal water movement. Guided by the Mualem Van-Genutchen theory (Additional file 1), bulkheads were found to reduce maximum hydraulic conductivity from $10 \mathrm{~cm} \mathrm{~h}^{-1}$ in the saturated soil to $0.019 \mathrm{~cm} \mathrm{~h}^{-1}$ at the top of the bulkheads at a height of $0.25 \mathrm{~m}$ from the bottom. Furthermore, subsurface irrigation is initiated only when the soil water content starts to fall within the compartments, 
thus further reducing the potential for horizontal flow (Fig. 7b, d). Also, the observed biomass response with lower grain yield and smaller kernel size combined with the increase in protein level in the midsection reflects classical yield-protein relations during drought, e.g. [57], rather than the movement of $\mathrm{N}$ due to subsurface irrigation. Importantly, since all genotypes are grown in rows perpendicular to the gradient, similar differences in soil $\mathrm{N}$ status are expected among the genotypes tested.

\section{Detecting water stress}

A novel element of this facility is the water-stress gradient created by rainout shelters and the subsurface irrigation system, inducing a visible response in the canopy. Current research observes drought symptom development in the canopy, using thermal and multispectral imaging (UASimaging), as well as manual scoring of drought symptoms (Fig. 11). This research also evaluates several other promising methods for quantifying differences between plant rows in temperature, leaf color or shape, each of which is a simple measure of how symptoms in individual genotypes develop over the distance from the border to the centerline of each unit. Of special interest is the use of thermal imaging, since leaf temperature is connected to changes in stomata conductance and is visible before any visible changes of form and color [58]. Such repeated and nondestructive measurements of the drought response in the canopy would provide valuable information for the detection of genotype performance across the gradient within the facility.

In both seasons, a statistically significant effect of position was observed. However, a sufficient available water content in the soil profile delayed the onset of drought symptoms until the grain-filling period. A similarly limited "drought effect" was seen in an lysimeter experiment using repacked soil to investigate drought tolearnce of spring sown wheat [59]. To stimulate the development of drought symptoms, improved management of the rainout shelters and the subsurface irrigation system could extend the period with dry conditions. Thus, a custom-designed drought treatments would improve the potential for detecting genotypic difference along the stress-gradient.

\section{The semi-field phenotyping approach}

Large-scale semi-field setups have been widely used to understand soil hydrology, nutrient dynamics and plant water uptake, e.g. [19, 60, 61]. Results presented here confirm the premise that a semi-field setup offers several advantages over field experiments. Firstly, the construction process allowed for easy installation the MR-phenotyping system, VWC sensors and a subsurface irrigation system that would have been challenging and time-consuming to set up under field conditions. In addition, permanent control over precipitation and soil water allows for improved reproducibility of the drought treatment. Finally, since high levels of residual variation often hamper field experiments due to differences in soil texture and water $[5,62]$, in-field variation is reduced in a semifield setup.

A similar reduction in field variation can be obtained by pot studies under controlled conditions. However, the use of a large soil volume with normal field nutrient levels avoids potentially confounding effects on plant physiology that are inherent to pot or container setups made with a smaller soil volume [63-66]. In addition, plants in the facility are exposed to natural levels of light, air temperature and, perhaps most importantly, soil temperature [67]. Nonetheless, the semi-field conditions within the facility do not address all variables that might be relevant to understand deep rooting under full field conditions. For instance, in the more compact subsoil found in fields, root growth could be restricted to biopores [44, $48,49,68,69]$. Also, constraints such as hypoxia, low
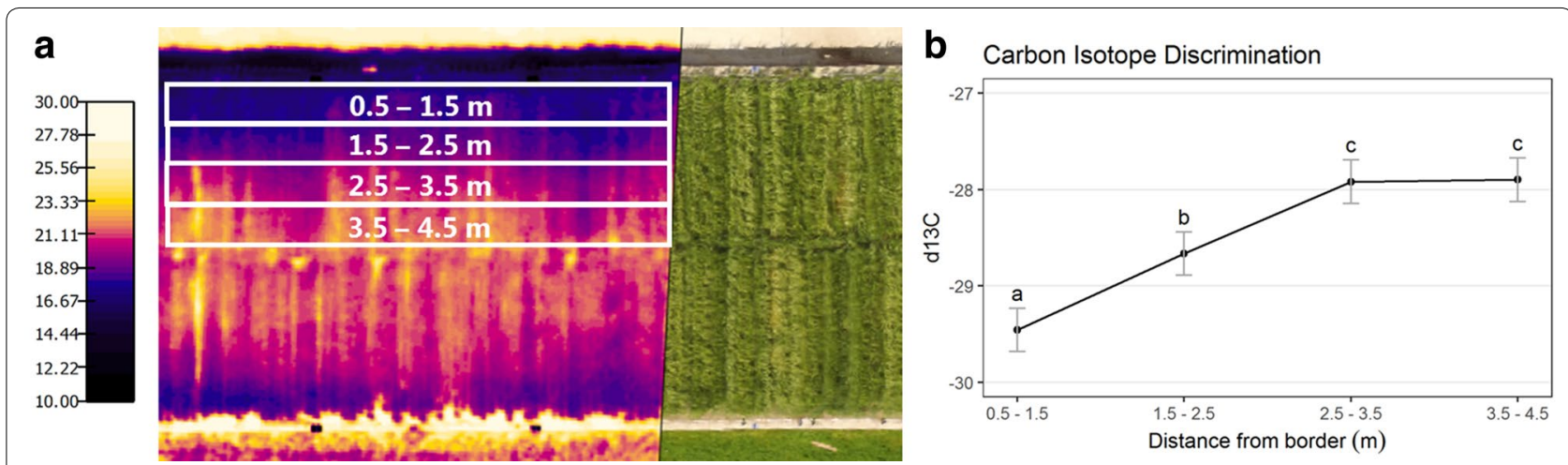

Fig. 11 Suggested methods for water stress observations. a Thermal imaging from an unmanned aerial vehicle showing canopy temperature $\left({ }^{\circ} \mathrm{C}\right)$, compared to RGB image of the crop and $\mathbf{b}$ carbon isotope discrimination ratio for the sampled area indicated on $\mathbf{a}$ 
soil temperature, soil acidity, aluminum and manganese toxicity, inadequate levels of calcium and phosphorus are known inhibitors for deep root growth in field conditions [46]. Of these, our facility provides low levels of phosphorus and suboptimal soil temperature in the early spring, compared to controlled greenhouse conditions. Furthermore, the soil bulk density of the subsoil is close to natural conditions of Danish subsoils of similar parent material $\left(60 \mathrm{~cm}=1.72 \mathrm{~g} \mathrm{~cm}^{-3}\right)$ [70]. However, due to the excellent drainage conditions and high soil $\mathrm{pH}$ caused by the natural presence of carbonates, problems with hypoxia, calcium deficiency and metal related toxicity problems are not likely to be replicated in the facility. Thus, it would be valuable to validate results of experiments in our RadiMax facility under real field conditions, to identify potential genotype $\times$ environment interactions.

Finally, the current size of $2 \times 150$ rows per experiment is large compared to other research setups aimed at understanding and identifying phenotypic differences in deep root growth, but still limited compared to the requirements in genetic investigations (e.g. quantitative trait locus or genome-wide association studies). Instead, a combined approach can be made by performing a larger proxy trait screen under controlled conditions, with subsequent validation of a subset of contrasting genotypes within the facility as suggested by [5].

\section{Summary and conclusion}

We successfully developed a new semi-field phenotyping system for the study of deep root growth and effective subsoil resource acquisition. The system offers a combined approach with direct measurements of root growth alongside detection of stress symptoms in the canopy, which represents a phenotyping through root function. A 2 year replicated spring barley experiment showed that phenotypic differences of deep root intensity could be repeated among spring barley cultivars and that clear aboveground physiological stress responses was visible along the water stress gradient.

The semi-field system offers labour-efficient and reproducible measurements of water and nutrient acquisition from deep soil layers of many genotypes compared to traditional field-based methods. Compared to in-house studies under controlled conditions, the semi-field condition enables the identification of relevant traits for full-scale crop development in an environment close to field conditions. In this way, we hope the semi-field facility concept will provide plant breeders with valuable data for the development of new robust and high yielding cultivars.

\section{Additional files}

Additional file 1. Measurements of soil physical properties and parameterisation of water balance model.

Additional file 2. Texture and chemical properties of top and subsoil in each unit of the RadiMax facility (Fine soil fraction $<2 \mathrm{~mm}$ ). The values are averages from two samples at each end of the unit, with the absolute difference in brackets. *Soil bulk density of the two sol layers measured at $0.25 \mathrm{~m}$ and $0.6 \mathrm{~m}$ in March 2017.

Additional file 3. Two-way ANOVA model output of biomass and root data from the 2017 season including the effect of the unit in the analysis.

\section{Abbreviations}

$\mathrm{ET}_{\mathrm{o}}$ : reference evapotranspiration; $\mathrm{ET}_{\mathcal{C}}$ : potential evapotranspiration; $\mathrm{MR}$ : minirhizotrons; N: nitrogen; pF: soil water potential; TDR: trans domain reflectometry; TDT: trans domain transmission; VWC: soil volumetric water content; UAS: unmanned aerial system.

\section{Authors' contributions}

KTK and CSJ obtained the grant and designed the project. SFS, KTK and CSJ developed the concept and built the facility. SFS and KTK designed the barley experiment, collected and analyzed the data and drafted the first manuscript. All authors read and approved the final manuscript.

\section{Author details}

1 Department of Plant and Environmental Science, University of Copenhagen, 1871 Frederiksberg, Denmark. ${ }^{2}$ Research Division, DLF Seeds A/S, 4660 Store Heddinge, Denmark.

\section{Acknowledgements}

Many people with valuable skills and technical knowledge were involved in the construction and development of the facility. We would like to acknowledge Jesper Svensgaard of the Department of Plant and Environmental Science, for valuable assistance during the planning and construction phase of the infrastructure, and also for providing UAV images. Si Chen, Tomke S. Wacker and numerous other colleagues at Copenhagen University and Aarhus University are gratefully acknowledged for technical assistance and data collection. Furthermore, the contributions of plant material and technical assistance from plant breeders at Sejet, Nordic Seed, DLF Trifolium and Danespo are also gratefully acknowledged. The project was funded by Innovation Fund Denmark, Crop Innovation Denmark, Promilleafgiftsfonden, Plan Danmark and Godfred Birkedal Hartmanns Familiefond.

\section{Competing interests}

The authors declare that they have no competing interests.

\section{Availability of data and materials}

The datasets used and/or analysed during the current study are available from the corresponding author on reasonable request. Furthermore, data related to soil physical properties and water balance modelling are available as supplementary material.

Consent for publication

Not applicable.

Ethics approval and consent to participate Not applicable.

\section{Funding}

The project was funded by the Innovation Fund Denmark (Grant No. 46-20141), Crop Innovation Denmark, Promilleafgiftsfonden, Plan Danmark and Godfred Birkedal Hartmanns Familiefond (Grant No. RadiMax).

\section{Publisher's Note}

Springer Nature remains neutral with regard to jurisdictional claims in published maps and institutional affiliations. 
Received: 17 December 2018 Accepted: 6 March 2019

Published online: 20 March 2019

\section{References}

1. Trenberth KE, Dai A, Van Der Schrier G, Jones PD, Barichivich J, Briffa $\mathrm{KR}$, et al. Global warming and changes in drought. Nat Clim Change. 2014:4:17-22. https://doi.org/10.1038/nclimate2067.

2. Spinoni J, Vogt JV, Naumann G, Barbosa P, Dosio A. Will drought events become more frequent and severe in Europe? Int J Climatol. 2018;38:1718-36. https://doi.org/10.1002/joc.5291.

3. Dalgaard T, Hansen B, Hasler B, Hertel O, Hutchings NJ, Jacobsen BH, et al. Policies for agricultural nitrogen management-trends, challenges and prospects for improved efficiency in Denmark. Environ Res Lett. 2014;9:115002. https://doi.org/10.1088/1748-9326/9/11/115002.

4. Dodd IC, Whalley WR, Ober ES, Parry MAJ. Genetic and management approaches to boost UK wheat yields by ameliorating water deficits. J Exp Bot. 2011;62:5241-8. https://doi.org/10.1093/jxb/err242.

5. Wasson AP, Richards RA, Chatrath R, Misra SC, Prasad SVS, Rebetzke GJ, et al. Traits and selection strategies to improve root systems and water uptake in water-limited wheat crops. J Exp Bot. 2012;63:3485-98. https:// doi.org/10.1093/jxb/ers111.

6. Blum A. Effective use of water (EUW) and not water-use efficiency (WUE) is the target of crop yield improvement under drought stress. Field Crop Res. 2009;112:119-23. https://doi.org/10.1016/j.fcr.2009.03.009.

7. Rasmussen IS, Dresbø\|IDB, Thorup-Kristensen K. Winter wheat cultivars and nitrogen (N) fertilization - effects on root growth, N uptake efficiency and N use efficiency. Eur J Agron. 2015;68:38-49. https://doi. org/10.1016/j.eja.2015.04.003.

8. Macdonald AJ, Poulton PR, Howe MT, Goulding KWT, Powlson DS. The use of cover crops in cereal-based cropping systems to control nitrate leaching in SE England. Plant Soil. 2005;273:355-73. https://doi. org/10.1007/s11104-005-0193-3.

9. Thorup-Kristensen K, Salmerón Cortasa M, Loges R. Winter wheat roots grow twice as deep as spring wheat roots, is this important for $\mathrm{N}$ uptake and N leaching losses? Plant Soil. 2009;322:101-14. https://doi. org/10.1007/s11104-009-9898-z.

10. Borg H, Grimes DW. Depth development of roots with time: an empirical description. Trans ASAE. 1986;29:194-7. https://doi.org/10.13031 /2013.30125.

11. Weaver J. Root development of field crops. New York: McGraw-Hill; 1926.

12. Böhm W. Untersuchungen zur Wurzelentwicklung bei Winterweizen. Zeitschrift für Acker- und Pflanzenbau. 1978;147:264-9.

13. do Rosário G. Oliveira M, van Noordwijk M, Gaze SR, Brouwer G, Bona S, Mosca G, et al. Auger sampling, ingrowth cores and pinboard methods. In: Root methods. Berlin: Springer; 2000. p. 175-210. https://doi. org/10.1007/978-3-662-04188-8_6.

14. Van Noordwijk M, Brouwer G, Meijboom F, Oliveira MRG, Bengough AG. Trench profile techniques and core break methods. Root methods a handbook; 2000. p. 211-33. https://doi.org/10.1007/978-3-662-04188-8_7.

15. Wasson A, Bischof L, Zwart A, Watt M. A portable fluorescence spectroscopy imaging system for automated root phenotyping in soil cores in the field. J Exp Bot. 2016;67:1033-43. https://doi.org/10.1093/jxb/erv570.

16. Vamerali T, Bandiera M, Mosca G. Minirhizotrons in modern root studies. In: Measuring roots: an updated approach. Berlin: Springer; 2012. p. 341-61. https://doi.org/10.1007/978-3-642-22067-8_17.

17. Rewald B, Ephrath J. Minirhizotrons techniques. In: Eshel A, Beeckman T, editors. Plant roots: the hidden half. 2013. p. 42.1-42.15.

18. Maeght J-L, Rewald B, Pierret A. How to study deep roots-and why it matters. Front Plant Sci. 2013:4:299. https://doi.org/10.3389/fpls.2013.00299.

19. Cai G, Vanderborght J, Klotzsche A, van der Kruk J, Neumann J, Hermes N, et al. Construction of minirhizotron facilities for investigating root zone processes. Vadose Zone J. 2016. https://doi.org/10.2136/vzj2016.05.0043.

20. Bragg PL, Govi G, Cannell RQ. A comparison of methods including angled and vertical minirhizotrons for studying root growth and distribution in a spring oat corp. Plant Soil. 1983;73:435-40. https://doi.org/10.2307/42934366.

21. De Ruijter FJ, Veen BW, Van Oijen M. A comparison of soil core sampling and minirhizotrons to quantify root development of field-grown potatoes. Plant Soil. 1996;182:301-12. https://doi.org/10.1007/BF00029061.
22. Trachsel S, Kaeppler SM, Brown KM, Lynch JP. Shovelomics: high throughput phenotyping of maize (Zea mays L.) root architecture in the field. Plant Soil. 2011:341:75-87.

23. Yang G, Liu J, Zhao C, Li Z, Huang Y, Yu H, et al. Unmanned aerial vehicle remote sensing for field-based crop phenotyping: current status and perspectives. Front Plant Sci. 2017;8:1111. https://doi.org/10.3389/ fpls.2017.01111.

24. Topp CN, lyer-Pascuzzi AS, Anderson JT, Lee C-R, Zurek PR, Symonova O, et al. 3D phenotyping and quantitative trait locus mapping identify core regions of the rice genome controlling root architecture. Proc Natl Acad Sci. 2013;110:E1695-704. https://doi.org/10.1073/pnas.1304354110.

25. Nagel KA, Putz A, Gilmer F, Heinz K, Fischbach A, Pfeifer J, et al. GROWSCREEN-Rhizo is a novel phenotyping robot enabling simultaneous measurements of root and shoot growth for plants grown in soil-filled rhizotrons. Funct Plant Biol. 2012;39:891-904. https://doi. org/10.1071/FP12023.

26. Pratap A, Tomar R, Kumar J, Vankat RP, Mehandi S, Katiyar PK. Highthroughput plant phenotyping platforms. In: Phenomics in crop plants: trends, options and limitations. New Delhi: Springer India; 2015. p. 285-96. https://doi.org/10.1007/978-81-322-2226-2_19.

27. Downie HF, Adu MO, Schmidt S, Otten W, Dupuy LX, White PJ, et al. Challenges and opportunities for quantifying roots and rhizosphere interactions through imaging and image analysis. Plant Cell Environ. 2015:38:1213-32. https://doi.org/10.1111/pce.12448.

28. Richard CAl, Hickey LT, Fletcher S, Jennings R, Chenu K, Christopher JT. High-throughput phenotyping of seminal root traits in wheat. Plant Methods. 2015;11:13. https://doi.org/10.1186/s13007-015-0055-9.

29. Manschadi AM, Hammer GL, Christopher JT, deVoil P. Genotypic variation in seedling root architectural traits and implications for drought adaptation in wheat (Triticum aestivum L.). Plant Soil. 2008;303:115-29. https://doi.org/10.1007/s11104-007-9492-1.

30. Robinson H, Kelly A, Fox G, Franckowiak J, Borrell A, Hickey L. Root architectural traits and yield: exploring the relationship in barley breeding trials. Euphytica. 2018. https://doi.org/10.1007/s10681-018-2219-y.

31. Topp GC, Davis JL, Annan AP. Electromagnetic determination of soil water content: measurements in coaxial transmission lines. Water Resour Res. 1980;16:574-82. https://doi.org/10.1029/WR016i003p 00574.

32. ISO 11277:2009. Soil quality — determination of particle size distribution in mineral soil material_-method by sieving and sedimentation. 2009. https://www.iso.org/standard/54151.html. Accessed 3 Sep 2018.

33. Sørensen NK, Bülow-Olsen A. Fælles arbejdsmetoder for jordbundsanalyser. Lyngby: Plantedirektoratet; 1994.

34. Bingham IJ, Karley AJ, White PJ, Thomas WTB, Russell JR. Analysis of improvements in nitrogen use efficiency associated with 75 years of spring barley breeding. Eur J Agron. 2012;42:49-58. https://doi. org/10.1016/j.eja.2011.10.003.

35. ISO 16634-2:2016. Food products-determination of the total nitrogen content by combustion according to the Dumas principle and calculation of the crude protein content-part 2: cereals, pulses and milled cereal products. 2016;24. https://www.iso.org/standard/66661.html. Accessed 1 Sep 2018

36. Allen RG, Pruitt WO, Wright JL, Howell TA, Ventura F, Snyder R, et al. A recommendation on standardized surface resistance for hourly calculation of reference ETo by the FAO56 Penman-Monteith method. Agric Water Manag. 2006;81:1-22. https://doi.org/10.1016/J.AGWAT 2005.03.007.

37. Vejen F, Vilic K, Jensen H. Korrigeret Nedbør 1989-2010, 2011-2012 \& 2013. DMI technical report 14-13. 2014.

38. Hansen S. Estimation of potential and actual evapotranspiration. Hydrol Res. 1984;15:205-12. https://doi.org/10.2166/nh.1984.017.

39. Pinheiro J, Bates D, DebRoy S, Sarkar D, R Core Team. \{nlme\}: Linear and nonlinear mixed effects models. 2016. http://cran.r-project.org/packa ge $=$ nlme. Accessed 23 Jan 2017.

40. Lenth RV. Least-squares means: the R package \{lsmeans\}. J Stat Softw. 2016;69:1-33.

41. Ephrath JE, Silberbush M, Berliner PR. Calibration of minirhizotron readings against root length density data obtained from soil cores. Plant Soil. 1999;209:201-8. https://doi.org/10.1023/A:1004556100253.

42. Mancuso PDS. Measuring roots-an updated approach. Berlin: Springer; 2012. https://doi.org/10.1007/978-3-642-22067-8. 
43. Nakaji T, Noguchi K, Oguma H. Classification of rhizosphere components using visible-near infrared spectral images. Plant Soil. 2007;310:245-61. https://doi.org/10.1007/s11104-007-9478-z.

44. Breuning Madsen H. Distribution of spring barley roots in Danish soils, of different texture and under different climatic conditions. Plant Soil. 1985;88:31-43. https://doi.org/10.1007/BF02140664.

45. Thorup-Kristensen K. Effect of deep and shallow root systems on the dynamics of soil inorganic N during 3-year crop rotations. Plant Soil. 2006;288:233-48. https://doi.org/10.1007/s11104-006-9110-7.

46. Lynch JP, Wojciechowski T. Opportunities and challenges in the subsoil: pathways to deeper rooted crops. J Exp Bot. 2015;66:2199-210. https:// doi.org/10.1093/jxb/eru508.

47. Macduff JH, Wild A, Hopper MJ, Dhanoa MS. Effects of temperature on parameters of root growth relevant to nutrient uptake: measurements on oilseed rape and barley grown in flowing nutrient solution. Plant Soil. 1986;94:321-32. https://doi.org/10.1007/BF02374326.

48. Hodgkinson L, Dodd IC, Binley A, Ashton RW, White RP, Watts CW, et al. Root growth in field-grown winter wheat: some effects of soil conditions, season and genotype. Eur J Agron. 2017;91:74-83. https://doi. org/10.1016/j.eja.2017.09.014.

49. Bengough AG, McKenzie BM, Hallett PD, Valentine TA. Root elongation, water stress, and mechanical impedance: a review of limiting stresses and beneficial root tip traits. J Exp Bot. 2011;62:59-68. https://doi. org/10.1093/jxb/erq350.

50. Malamy JE. Intrinsic and environmental response pathways that regulate root system architecture. Plant Cell Environ. 2005;28:67-77. https:// doi.org/10.1111/j.1365-3040.2005.01306.x.

51. Zhang H, Jennings A, Barlow PW, Forde BG. Dual pathways for regulation of root branching by nitrate. Proc Natl Acad Sci. 1999;96:6529-34. https://doi.org/10.1073/pnas.96.11.6529.

52. Kristensen $\mathrm{HL}$, Thorup-Kristensen K. Effects of vertical distribution of soil inorganic nitrogen on root growth and subsequent nitrogen uptake by field vegetable crops. Soil Use Manag. 2007;23:338-47. https ://doi.org/10.1111/j.1475-2743.2007.00105.x.

53. Faget $M$, Liedgens $M$, Stamp $P$, Flütsch $P$, Herrera JM. A minirhizotron imaging system to identify roots expressing the green fluorescent protein. Comput Electron Agric. 2010;74:163-7. https://doi.org/10.1016/j. compag.2010.06.010.

54. Cai G, Vanderborght J, Couvreur V, Mboh CM, Vereecken H. Parameterization of root water uptake models considering dynamic root distributions and water uptake compensation. Vadose Zone J. 2017. https:// doi.org/10.2136/vzj2016.12.0125.

55. Shelia V, Šimunek J, Boote K, Hoogenbooom G. Coupling DSSAT and HYDRUS-1D for simulations of soil water dynamics in the soil-plantatmosphere system. J Hydrol Hydromech. 2018;66:232-45. https://doi. org/10.1515/johh-2017-0055.

56. Wilkison DH, Blevins DW. Observations on preferential flow and horizontal transport of nitrogen fertilizer in the unsaturated zone. J Environ Qual. 1999;28:1568-80. https://doi.org/10.2134/jeq1999.0047242500 2800050022x.

57. Terman GL, Ramig RE, Dreier AF, Olson RA. Yield-protein relationships in wheat grain, as affected by nitrogen and water. Agron J. 1969;61:755. https://doi.org/10.2134/agronj1969.00021962006100050031x.
58. Ludovisi R, Tauro F, Salvati R, Khoury S, Mugnozza Scarascia G, Harfouche A. UAV-based thermal imaging for high-throughput field phenotyping of black poplar response to drought. Front Plant Sci. 2017:8:1681. https://doi.org/10.1109/AMS.2009.139.

59. Meyer W, Tan C, Barrs H, Smith R, Meyer W, Tan C, et al. Root growth and water uptake by wheat during drying of undisturbed and repacked soil in drainage lysimeters. Aust J Agric Res. 1990;41:253. https://doi. org/10.1071/AR9900253.

60. Goss MJ, Ehlers W. The role of lysimeters in the development of our understanding of soil water and nutrient dynamics in ecosystems. Soil Use Manag. 2009;25:213-23. https://doi.org/10.111 1/j.1475-2743.2009.00230.x.

61. Eberbach PL, Hoffmann J, Moroni SJ, Wade LJ, Weston LA. Rhizo-lysimetry: facilities for the simultaneous study of root behaviour and resource use by agricultural crop and pasture systems. Plant Methods. 2013;9:3. https://doi.org/10.1186/1746-4811-9-3.

62. Zipper SC, Soylu ME, Booth EG, Loheide SP. Untangling the effects of shallow groundwater and soil texture as drivers of subfield-scale yield variability. Water Resour Res. 2015;51:6338-58. https://doi. org/10.1002/2015WR017522.

63. Poorter H, Fiorani F, Pieruschka R, Wojciechowski T, van der Putten WH, Kleyer $\mathrm{M}$, et al. Pampered inside, pestered outside? Differences and similarities between plants growing in controlled conditions and in the field. New Phytol. 2016;212:838-55. https://doi.org/10.1111/nph.14243.

64. Poorter H, Bühler J, van Dusschoten D. Pot size matters: a metaanalysis of the effects of rooting volume on plant growth. Funct Plant Biol. 2012;39:839-50. http://www.publish.csiro.au/?paper=FP12049. Accessed 16 Dec 2012.

65. Chapman N, Miller AJ, Lindsey K, Whalley WR. Roots, water, and nutrient acquisition: let's get physical. Trends Plant Sci. 2012;17:701-10. https://doi.org/10.1016/J.TPLANTS.2012.08.001.

66. Turner NC. Imposing and maintaining soil water deficits in drought studies in pots. Plant Soil. 2018. https://doi.org/10.1007/s1110 4-018-3893-1.

67. Füllner K, Temperton VM, Rascher U, Jahnke S, Rist R, Schurr U, et al. Vertical gradient in soil temperature stimulates development and increases biomass accumulation in barley. Plant Cell Environ. 2012;35:884-92. https://doi.org/10.1111/j.1365-3040.2011.02460.x.

68. White RG, Kirkegaard JA. The distribution and abundance of wheat roots in a dense, structured subsoil-implications for water uptake. Plant Cell Environ. 2010;33:133-48. https://doi.org/10.111 1/j.1365-3040.2009.02059.x.

69. Gao W, Hodgkinson L, Jin K, Watts CW, Ashton RW, Shen J, et al. Deep roots and soil structure. Plant Cell Environ. 2016;39:1662-8. https://doi. org/10.1111/pce.12684.

70. Greve HM, Greve BM, Sørensen B, Larsen R, Tind SL. Soil profile 674 tune. DJFgeodata: Beskrivelse af geografiske data ved afdelingen. 2004. http:// www.djfgeodata.dk/jordbund/674.pdf. Accessed 4 Feb 2019.

\footnotetext{
Ready to submit your research? Choose BMC and benefit from:

- fast, convenient online submission

- thorough peer review by experienced researchers in your field

- rapid publication on acceptance

- support for research data, including large and complex data types

- gold Open Access which fosters wider collaboration and increased citations

- maximum visibility for your research: over $100 \mathrm{M}$ website views per year
}

At BMC, research is always in progress.

Learn more biomedcentral.com/submissions 